\title{
DINAMIKA ISLAM POLITIK DI INDONESIA PADA ERA REFORMASI (1998-2001) ${ }^{1}$
}

\section{Kamaruzzaman Bustamam-Ahmad}

Mahasiswa Pascasarjana (S2) University of Malaya Kuala Lumpur

ملخص

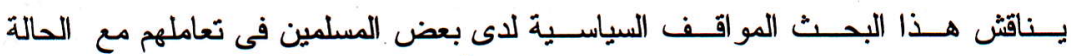

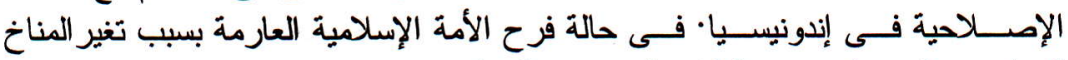

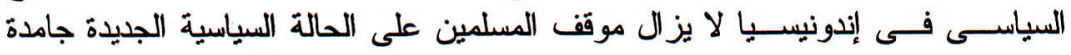

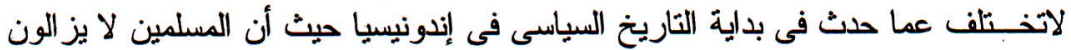

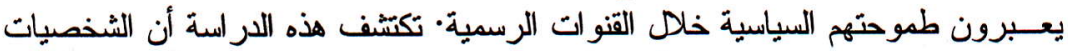

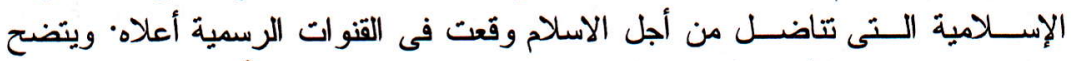

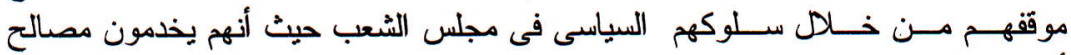

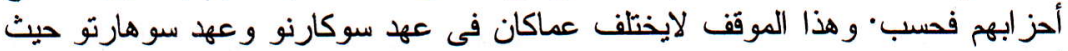

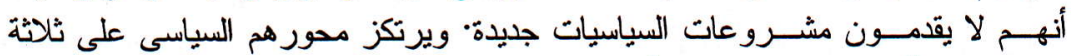

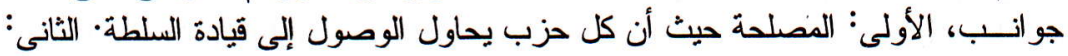

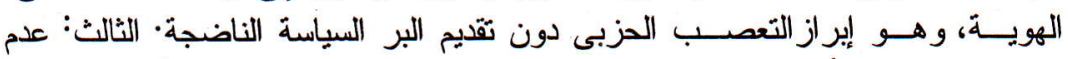

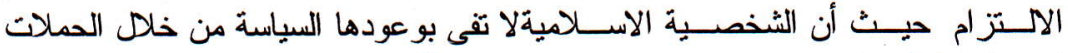

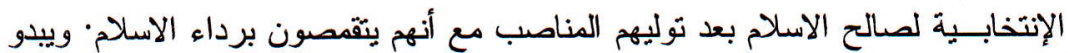

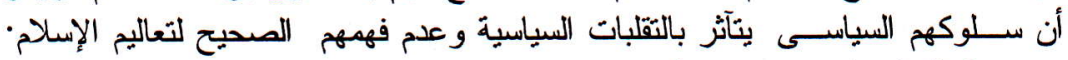

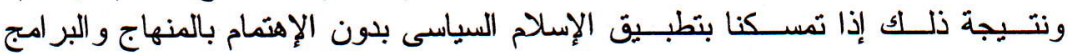

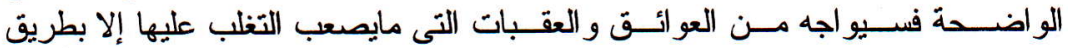

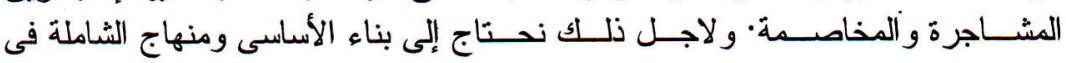
تفسير الاحداث السياسية في إندونيسيا. ولاجئ.

${ }^{1}$ Dalam penyusunan artikel ini, penulis ingin mengucapkan terima kasih kepada Robert W. Hefner, Howard M. Federspiel, Eep Saefullah Fatah, dan Mohd. Zaidi Abdul Rahman yang telah memberikan beberapa pandangan awal terhadap draft tulisan ini. Demikian juga kepada Dwi Ratih Kholisah yang telah mengedit beberapa bagian naskah ini. Namun demikian, isi dan substansi tulisan ini adalah tanggung jawab penulis. 


\section{Abstract}

This article discusses the political attitude of some Indonesian Muslims to the reformation era of Indonesia. Euphorically, they responded the reformation in the same way as in the early history of Indonesian politics, i.e., they are interested much in struggling their political interest in the formalistic ways. This study bas found that the Islamic figures who struggling political Islam in the substantive ways are entrapped in formalistic struggle. Compared to the era of Old and New Order political system, some politician Muslims bardly offer new political strategies. Their political attitudes have been promoted so far are merely on the following three points. First is an interest to raise their political parties to the power. Second is to pose their groups without any good quality agenda. Third, inconsistency of some figure in struggling for Muslim society, they struggle for their own group instead. It seems that the attitude of some elite politician Muslims is influenced by political changes and their religious understandings. It is clear that if political Islam is struggled without any good and distinct concept or agenda, the politician Muslims would face some obstacles which are difficult to be solved. Therefore, basic wide-ranging understanding is necessary for politician Muslims in comprehending some political affairs in Indonesia.

Keywords: Islam politik, reformasi, asas \& simbol Islam, nilai Islam, nasionalis-sekuler

Sejarah politik Islam Indonesia modern sebenarnya merupakan khazanah perbandingan yang cukup lumayan dibandingkan dengan pemikiranpemikiran politik keislaman yang pernah yang dikembangkan di kawasan Timur Tengah atau dunia Islam lainnya.

(Bahtiar Effendy) ${ }^{2}$

\section{A. Pendahuluan}

Tulisan ini bermaksud mengkaji dinamika Islam politik di Indonesia pada era reformasi. ${ }^{3}$ Dalam hal ini penulis berpendapat bahwa keberadaan

2Bahtiar Effendy, "Disartikulasi Pemikiran Politik Islam?" dalam Olivier Roy, Gagalnya Islam Politik, terj. Harimurti dan Qomaruddin SF (Jakarta: Serambi Ilmu Semesta, 2002), hlm. viii.

${ }^{3}$ Untuk memahami bagaimana perkembangan politik pada era reformasi, baca beberapa karya berikut: Bilveer Singh, Succession Politics in Indonesia: The 1998 Presidential Elections and the Fall of Soeharto (London: Macmillan, 2000); Geoff Forrester \& R.J. May 
Islam politik di Indonesia tidak pernah terputus dengan isu-isu "klasik". Maksudnya, persoalan yang dihadapi umat Islam pada era reformasi, hampir sama dengan persoalan yang dihadapi tokoh-tokoh politik pada masa pra dan pasca kemerdekaan bangsa Indonesia. Hanya saja pada era reformasi, "kran" politik umat Islam terbuka lebar, namun tokoh-tokoh politiknya tidak memiliki orientasi yang jelas dalam mengisi reformasi itu sendiri.

Setelah pendahuluan, selanjutnya kajian ini mengulas format Islam politik yang berkembang pada era reformasi. Dalam hal ini, penulis melihat bahwa kecenderungan tokoh-tokoh Islam untuk kembali memperjuangkan Islam politik, lebih banyak dipengaruhi oleh situasi sosial politik saat itu. Setelah itu, akan diuraikan perkembangan partai-partai politik dari kalangan Islam dalam pemilu $1999 .{ }^{4}$ Dari sini kemudian ditelusuri nilai-nilai politik yang dipraktekkan oleh tokoh politik dari kalangan umat Islam.

\section{B. Mencari Bentuk Format Islam Politik}

Sebagai pengkaji politik Islam pada era Orde Baru, Bahtiar Effendy menyimpulkan bahwa arus utama politik Islam pada masa Orde Baru bersifat substansialis. Artinya, para pemikir dan aktivis politik Islam berusaha untuk lebih mengedepankan hal-hal yang berkaitan dengan makna, isi, dari pada bentuk dan simbol. ${ }^{5}$ Dengan begitu, strategi Islam politik telah terpolarilasasi menjadi dua kutub yakni substantivistik dan formalistik. Kelompok pertama tetap konsisten dengan tidak memasuki politik praktis, dengan format politik yang bertumpu pada substansialisme Islam. Adapun kelompok kedua yang menghendaki adanya perjuangan politik, ternyata telah menjadi sumberdaya politik pelaku politik Islam. Pada saat yang sama, kelompok ini juga memiliki kelemahan yakni

(ed.), The Fall of Soeharto (Singapore: Select Books 1999); Geoff Forrester (ed.), PostSoeharto Indonesia: Renewal or Chaos? (Singapore: Institute of Southeast Asian Studies, 1999).

${ }^{4}$ Kajian terkini tentang pemilu 1999, lihat Leo Suryadinata, Elections and Politic in Indonesia (Singapore: Institute of Southeast Asian Studies, 2002).

5Bahtiar Effendy, "Politik Islam Pasca Orde Baru: Sintesa antara Substansialisme dan Simbolisme?”, Republika, 15-16 November 1999. 
orientasi yang berlebihan terhadap simbol, telah ikut mendatangkan akibatakibat yang tidak menguntungkan bagi Islam. ${ }^{6}$

Menurut John L. Esposito dan John O. Voll, ada empat posisi umum sebagai pilihan bagi gerakan kebangkitan Islam (reformasi). Pertama, oposisi revolusioner terhadap sistem politik yang ada; kedua, oposisi yang diakui atau bekerja sama dengan beroperasi dalam sistem politik yang ada; ketiga, partisipasi aktif dalam pemerintah melalui aliansi atau koalisi dengan kekuatan-kekuatan politik lain, dan keempat, kekuatan kontrol dalam sistem politik yang ada. ${ }^{7}$

Sementara itu, Saiful Mujani mengatakan bahwa oposisi adalah sikap dan kekuatan politik untuk memperlemah atau bahkan menjatuhkan pemerintah yang mengalahkannya dalam persaingan untuk merebut kekuasaan. ${ }^{8}$ Menurutnya, ada dua isu yang dapat disebut sebagai kekuatan oposisi pada masa Orde Reformasi, yakni isu teknis dan isu simbolik. Isu teknis berkaitan dengan program-program spesifik yang dapat dipecahkan secara teknis seperti penanggulangan krisis ekonomi, penegakan hukum, pemberantasan $\mathrm{KKN}$, penyediaan lapangan kerja, dan memperkuat hubungan luar negeri. Isu-isu simbolik menyangkut sentimen primordial massa, yang secara tiil dirasakan adanya oleh masyarakat, tetapi tidak mudah dipecahkan. Pembedaan agama, daerah, suku, dan etnik, termasuk ke dalam isu-isu simbolik ini. ${ }^{9}$ Nampaknya Mujani mengaitkan isu simbolik ini dengan konsep identitas yang berkembang dalam konsep negara-bangsa (nation-state) $^{10}$ yang sering didengungkan oleh kelompok sekularis di Indonesia.

Lebih dari itu, sejak era reformasi umat Islam juga terbagi ke dalam beberapa bentuk perjuangan. Bentuk pertama dengan mendirikan partai,

'Ibid. Mengenai simbol Islam dalam politik Indonesia baca Nurcholish Madjid, "Simbol dan Simbolisme Keagamaan Populer serta Pemaknaannya dalam Perkembangan Sosial-Politik Nasional Kontemporer", Mukaddimah No. 8, Th. V, 1999, hlm. 1-41.

7John L. Esposito dan John O. Voll, Demokrasi di Negara-Negara Muslim: Problem dan Prospek (Bandung: Mizan, 1999), hlm. 40.

8Saiful Mujani, “Oposisi Islam?”, Republika, 27-28 Desember 1999.

9Ibid.

${ }^{10}$ Tentang hal ini, baca misalnya Martha L. Cottam dan Richard W. Cottam, Nationalism \& Politics: The Political Behavior of Nation States (London: Lynne Rienner, 2001), hlm. 28-32. 
baik yang berbasiskan massa Islam, memakai ideologi Islam, ${ }^{11}$ atau secara resmi menyebutkan diri sebagai partai Islam. Bentuk ini kemudian merealisasikan aspirasi umat Islam untuk mencapai puncak kekuasaan di Indonesia, baik dalam lini legislatif maupun eksekutif.

Dalam era reformasi, umat Islam masih memainkan peranan yang sangat penting, demikian juga ketika Soeharto lengser. ${ }^{12}$ Namun demikian, perkembangan Islam politik di Indonesia pada masa tersebut dapat dikatakan menemukan kebingungan, sebagaimana dinyatakan Eep Saefulloh Fatah berikut:

Belum habis periode "bulan madu" kalangan "Islam politik" dengan negara Orde Baru yang berlangsung sejak awal 1990-an, tiba-tiba saja situasi politik berubah menjadi sangat membingungkan dengan jatuhnya Soeharto pada 21 Mei 1998. Soeharto, yang pada awalnya dipahami oleh kalangan Islam politik sebagai "pintu," "instrumen," bahkan "patron" dalam upaya memperbesar akomodasi dan representasi politik Islam, tiba-tiba diposisikan sebagai musuh bersama publik, bahkan oleh sebagian besar kalangan Islam sekalipun. Sementara itu, B.J. Habibie, pengganti Soeharto yang belum siap sepenuhnya menjadi penguasa baru, secara tiba-tiba mesti dipaksakan menjadi "pintu," "instrumen," atau "patron" baru. ${ }^{13}$

Setidaknya ada tiga hal yang dihadapi oleh "Islam politik" pada era reformasi yaitu: pertama, situasi politik yang berubah secara mendadak yang mengakibatkan umat Islam harus memikirkan kembali strategi politiknya. Hal ini menyangkut agenda yang mesti dilakukan dalam jangka pendek dan jangka panjang. Situasi ini pada awalnya tanpa prediksi lengser-nya Soeharto dari kekuasaan. Meski ada prediksi tanda-tanda Soeharto akan turun, namun cara Soeharto mundur membuat umat Islam kebingungan, sehingga

\footnotetext{
${ }^{11}$ Menurut Nurcholish Madjid, Islam bukanlah sebuah ideologi, meskipun ia dapat berfungsi sebagai sumber ideologi bagi pemeluknya. Tetapi Islam sendiri terbebas dari keterbatasan-keterbatasan sebuah ideologi yang sangat memperhatikan konteks ruang dan waktu. Lihat Nurcholish Madjid, Cita-Cita Politik Islam Era Reformasi (Jakarta: Paramadina, 1999), hlm. 47.

${ }^{12}$ Ketika Soeharto jatuh, istilah lengser keprabon sering disebutkan oleh media massa atau tokoh politik. Untuk mengetahui istilah tersebut, lihat Franz Magnis-Suseno, "Langsir Keprabon: New Orde Leadership, Javanese Culture, and the Prospects for Democracy in Indonesia", dalam Forrester (ed.), Post-Soebarto Indonesia, hlm. 214-228.

${ }^{13}$ Eep Saefulloh Fatah, "Masa Depan Politik Islam: Dari Pusaran Menuju Arus Balik”, dalam Abu Zahra (ed.), Politik Demi Tuhan: Nasionalisme Religius (Bandung: Pustaka Hidayah, 1999), hlm. 13-14.
} 
mengharuskan para elit politik Islam memikir ulang strategi yang sesuai dengan konteks reformasi.

Kedua, persoalan menyangkut Soeharto yang pada awalnya dipandang sebagai sekutu untuk membangun Islam politik, namun pada akhirnya menjadi musuh publik. Di samping itu, kelompok nasionalis-sekuler (pengikut Soekarno) yang selama ini menjadi rival politik Soeharto, juga menjadi persoalan tersendiri dan harus menjadi pertimbangan pula bagi Islam politik dalam menjalankan agendanya.

Ketiga, faktor Habibie sebagai kepala pemerintahan transisi, sebagaimana penilaian A. Syafii Maarif bahwa pada dasarnya Habibie seorang yang baik, namun datang pada waktu yang salah (a right man on the wrong time). Ia merupakan korban dari sistem ciptaan pendahulunya yang tidak segera disadarinya. Kepekaannya terhadap lingkungan politik yang keras dan kejam terasa kurang. ${ }^{14}$ Karena itu, legitimasi pemerintahan Habibie sangat lemah dibandingkan dua presiden sebelumnya, sehingga dukungan terhadapnya sangat minim, termasuk dari bekas kawan dekat Soeharto dan anggota Golkar. ${ }^{15}$ Habibie dianggap sebagai simbol Orde Baru, yang juga menyebabkannya banyak ditentang oleh kelompokkelompok Islam yang merasa dirugikan oleh pemerintahan yang banyak memarginalkan politik umat Islam tersebut. Karena itu umat Islam mengalami "kebingungan" dalam menyusun format politik yang tepat untuk diterapkan pada era reformasi. Sehingga ketika itu, Islam politik mengalami beberapa "guncangan" baik dalam bentuk konsep maupun gerakan.

Sedangkan menurut Amien Rais, setidaknya ada empat masalah yang dihadapi umat Islam ketika Soeharto turun. Pertama, sangat berkaitan

${ }^{14}$ Ahmad Syafii Maarif, "Soekarno Memulai, Soeharto Menyempurnakan, dan Habibie yang Jadi Korban", Republika, 19 November 1999. Lihat juga Paridah Abd. Samad, General Wiranto: The Man Emerging from the Midst of Indonesian Reformation (Kuala Lumpur: Affluent Master Sdn. Bhd., 1999), hlm. 51-54.

${ }^{15}$ Dalam hal ini, Nurcholish Madjid berpendapat: "He faced pressures from the public to solve the crisis ASAP. The pressures actually can be reduced if he comes out with a right dealing for example not giving medals in this difficult situation. Such award reflected how he has no sense of crisis. Worse, he gave one to his wife. It is Habibie's political deformity". Lihat Nurcholish Madjid, "Habibie: An Example of a Weak President that Should be Maintained Until the Election", Tempo Interaktif, Edisi 25/03, 22 Agustus 1998. 
dengan kekerasan yang dilakukan oleh negara ${ }^{16}$ terhadap masyarakat Muslim di beberapa propinsi di Indonesia selama Soeharto berkuasa. Kedua, munculnya beberapa partai dari organisasi dan gerakan Islam yang terlibat dalam pemilu. Ketiga, persoalan mengenai bagaimana nilai-nilai Islam mampu diaplikasikan dalam permasalahan sosial dan politik. Keempat, isu tentang pertanyaan "bagaimana" mencapai kehidupan demokrasi dalam masyarakat seperti Indonesia. ${ }^{17}$

Lebih jauh menurut Eep Saefulloh Fatah, partisipasi politik $^{18}$ yang berlaku di kalangan Islam, menemukan tiga indikasi di tengah suasana reformasi yaitu, (1) indikasi bahwa umumnya kalangan Islam mengalami repolitisasi, namun masih belum matang dan sulit ditebak format dan arahnya, (2) indikasi bahwa umumnya kalangan Islam juga mengalami reintegrasi, terutama kalangan Islam yang sedikit banyak memahami B.J. Habibie sebagai simbol Islam, dan (3) indikasi bahwa umumnya kalangan Islam juga mengalami (re)fragmentasi dan (re)disintegrasi serius, sehingga terbelah ke dalam faksi-faksi yang tidak saja berbeda namun juga potensial saling bertikai. ${ }^{19}$ Beberapa kekeliruan ini, ${ }^{20}$ tampaknya memberikan dampak

${ }^{16}$ Mengenai kekerasan negara terhadap umat Islam di Indonesia, lihat Mestika Zed, "Hidden History: Sejarah Kebrutalan dan Kejahatan Negara Melawan Kemanusiaan. IsuIsu dan Strategi dalam Konteks Sejarah Indonesia”, Jurnal Demokrasi \& HAM, Vol. 2, No. 1, Februari-Mei, 2002, hlm. 6-37.

${ }^{17}$ Amien Rais, "Islam and Politics in Contemporary", dalam Forrester (ed.), PostSoebarto Indonesia, hlm. 200-201.

${ }^{18}$ Tentang partisipasi politik, lihat Anthony H. Birch, The Concept and Theories of Modern Democracy (New York: Routledge, 2001), hlm. 104-118; Barrie Axford dan Ben Rosamond, "Political Participation", dalam Barrie Oxford et.al., Politic An Introduction (London: Routledge 1997), hlm. 197-137.

${ }^{19}$ Eep Saefulloh Fatah, "Menuju Masa Depan Politik Islam yang Toleran: Membangun Publik dan Oposisi," (Makalah dikirim kepada penulis melalui email, fatah.1@osu.edu, 20 Februari 2002). Lihat juga Fatah, "Menuju Format Baru Politik Islam: Belajar dari Kekeliruan Politik Lama", dalam Zahra (ed.), Politik Demi, hlm. 393.

${ }^{20}$ Dalam tulisannya "Menuju Format Baru Politik Islam", Eep juga menyebutkan lima kekeliruan politik kalangan Islam. Pertama, kalangan umat Islam lebih sering atau lebih suka marah ketimbang melakukan politisasi. Kedua, kalangan Islam sering lebih senang mengurusi kulit, bukan isi. Ketiga, politik kalangan Islam sering lebih terpesona pada keaktoran (figure; pelaku), bukan pada isme atau wacana yang diproduksinya. Keempat, politik kalangan Islam sering melakukan reaksi, dan bukan proaksi. Kelima, kalangan Islam sangat sering dan senang membuat kerumunan, dan bukan barisan. Lihat Fatah, "Menuju Format", hlm. 393-397. 
yang serius terhadap Islam politik di Indonesia, setidak-tidaknya tampak pada agenda-agenda umat Islam dalam menjalankan agenda reformasi.

Adapun pola kedua adalah keinginan umat Islam untuk bersatu dalam rangka mengisi refomasi. Keinginan ini tentu saja memerlukan tokoh-tokoh kharismatik dan dapat diterima umat Islam. Bagaimanapun juga usaha ini tidak akan memberikan kesan yang mendalam terhadap Islam politik. Hal ini disebabkan oleh aliran-aliran pemikiran yang dianut para tokoh-tokoh Islam di Indonesia beragam, yang mengakibatkan aktivitas politik umat Islam beragam pula, sehingga menyulitkan mereka untuk bersatu dalam perjuangan politik. Persatuan di antara elit politik Islam terkadang hanya untuk kepentingan sesaat. Setelah tujuan tercapai, mereka kembali lagi ke partai asal untuk mengedepankan kepentingan masing-masing.

\section{Pro-Kontra Pendirian Partai Politik di Kalangan Umat Islam}

Terhadap pendirian partai politik Islam pada era reformasi, terdapat perdebatan antara yang pro dan yang kontra di kalangan umat Islam. Kendati pada era Orde Baru partai politik Islam tidak begitu disukai oleh penguasa dan pemikir Islam terkemuka, namun hal tersebut tidak lagi berlaku pada era reformasi. Misalnya, Nurcholish Madjid yang sering melontarkan slogan "Islam Yes, Partai Islam, No!" secara tersirat mendukung pendirian partai-partai politik dari kalangan Islam. Menurut nya, politik adalah satu bentuk ekspresi yang paling tepat, terutama pasca Orde Baru. ${ }^{21}$ Pada tahap ini, tampaknya Nurcholish mulai meruntuhkan tesisnya tentang pemisahan antara urusan dunia dan agama dengan mengatakan:

Jadi, ekspresi politik merupakan kelanjutan atau kontinium dari gerakan dakwah. Kalau ada yang mengatakan bahwa hal itu karena kegagalan dakwah, saya kira tidak sama sekali. ... Sebab, apapun kegiatan seseorang atau kelompok dalam masyarakat, terutama yang

${ }^{21}$ Nurcholish Madjid, "Partai Keadilan Nanti Muncul Sebagai Partai Penting", dalam Hairus Salim (ed.), Tujuh Mesin Pendulang Suara: Perkenalan, Prediksi, Harapan Pemilu 1999 (Yogyakarta: LKiS, 1999), hlm. 193. 
mempunyai dimensi sosial yang luas pasti mempunyai dimensi lain, termasuk politik. ${ }^{22}$

Ia bahkan tidak lagi memandang kemunculan partai di kalangan Islam sebagai gejala fundamentalisme Islam atau formalisme Islam, ${ }^{23}$ sebagaimana pandangan sebagian orang ketika munculnya PK (Partai Keadilan). Menurut Nurcholish, hal itu hanya kesan yang merupakan tanggapan psikologis atau tanggapan yang lebih banyak bersifat kejiwaan, jadi belum ada buktinya. ${ }^{24}$ Perubahan ini terjadi setelah ia melihat bahwa partai-partai sekarang ini lebih terbuka dari partai-partai Islam masa lalu. ${ }^{25}$ Karena itu, ia menyimpulkan bahwa dalam memilih partai pada pemilu, sudah tidak begitu relefan lagi mempertimbangkan apakah partai itu bernama Islam atau tidak. ${ }^{26}$ Namun demikian, ia tetap konsisten untuk tidak mendirikan maupun melibatkan diri dalam partai politik manapun.

Adanya beberapa tokoh yang pada masa Orde Baru tidak berniat mendirikan atau bergabung dengan partai politik, lalu kemudian pada era reformasi mendirikan partai politik, merupakan fenomena menarik. Menurut Yusril Ihza Mahendra, ${ }^{27}$ berdasarkan asas kedaulatan rakyat maka pemerintah harus ditentukan oleh rakyat. Menurutnya, hingga sekarang belum ditemukan cara lain untuk mengakomodasi kehendak rakyat yang beragam kelompok, aliran, dan sebagainya, selain melalui partai politik. Untuk itu, siapa saja boleh mendirikan partai politik, walaupun partai itu banyak mudaratnya. ${ }^{28}$ Bagi Yusril sendiri, orang Islam yang ingin mendirikan partai Islam dengan nama Islam atau tidak, bukan persoalan

${ }^{22}$ Ibid.

${ }^{23}$ Pendapat Nurcholish tentang ini, lihat Nurcholish Madjid, "Beberapa Renungan Kehidupan Keagamaan Untuk Generasi Mendatang”, dalam Edy A. Effendy (ed.), Dekonstruksi Islam: Mą̧ab Ciputat (Bandung: Zaman Wacana Mulya, 1999), hlm. 20-23.

${ }^{24}$ Ibid., hlm. 193.

${ }^{25}$ Ibid., hlm. 194.

${ }^{26}$ Madjid, "Partai Keadilan”, hlm. 195.

${ }^{27}$ Tentang Yusril Ihza Mahendra, lihat Sidarta Gautama dan Aris Boediono, Moralitas Politik dan Pemerintahan Yang Bersih (Jakarta: Raja Grafindo Persada, 1999), hlm. 25-30. Baca juga Adian Husaini, Yusril Versus Masyumi: Kritik Terhadap Pemikiran Modernisme Islam Yusril Ihra Mahendra Jakarta: Dea Press, 2000).

${ }^{28} Y u s r i l$ Ihza Mahendra, "Partai Alternatif Era Reformasi", dalam Sahar L. Hassan et.al. (ed.), Memilih Partai Islam: Visi, Misi, dan Persepsi (Jakarta: Gema Insani Press, 1998), hlm. 121. 
fundamental. Persoalan fundamental adalah bagaimana agar partai itu sesuai dengan prinsip, jiwa, dan semangat Islam. ${ }^{29}$

Sementara itu, Deliar Noer menegaskan bahwa partai Islam tidak pernah turut merusak persatuan dan kesatuan bangsa Indonesia, karena partai Islam memiliki tujuan untuk menegakkan persatuan dan kesatuan serta berusaha mewujudkan cita-cita kemerdekaan, seperti kesejahteraan rakyat, demokrasi, keadilan dalam hukum, politik, dan ekonomi, serta dengan sendirinya melindungi dan menegakkan hak asasi manusia. ${ }^{30}$

Adapun M. Amien Rais mempunyai alasan tersendiri dalam mendirikan partai politik. Kendati pernah menyatakan bahwa karena ia berjuang di organisasi Muhammadiyah, maka sampai kapan pun ia tidak akan masuk partai politik -meskipun misalnya perubahan kehidupan politik menjadi lebih baik- ${ }^{31}$ namun mengingat proses reformasi masih setengah jalan, ia memutuskan untuk hijrah ke dunia politik. Amien mengatakan:

Saya sudah mendukung kereta reformasi mencapai seperempat jalan.

Jalan berikutnya masih panjang. Kalau saya lari sama halnya dengan tinggal gelanggang colong playu. Kemudian, teman-teman juga mengingatkan bahwa jauh sebelum reformasi saya sudah menggunakan moral force, berteriak dari kejauhan untuk menghancurkan korupsi, mengusik Busang dan lain-lain. Menurut mereka, pada alam reformasi ini saya harus hijrah dari dunia moral ke dunia politik. Itu lebih konkret. Kalau saya berhasil menggandeng moral dan politik dalam satu paket, mudah-mudahan saya dapat membangun Indonesia Baru secara lebih mantap. ${ }^{32}$

Berkaitan dengan pendirian partai politik, A.M Fatwa ${ }^{33}$ berpendapat bahwa keberadaan partai Islam akan menimbulkan beberapa pengaruh, baik positif maupun negatif. Adapun pengaruh positifnya ialah, (1) rakyat akan semakin terbuka menyalurkan aspirasi politiknya, tanpa intimidasi, (2) proses sosial politik akan lebih terbuka dan transparan sehingga budaya

${ }^{29} \mathrm{Ibid}$., hlm. 123.

${ }^{30}$ Noer, "Mengapa Partai Islam", dalam Hassan et.al. (ed.), Memilih Partai, hlm. 85.

${ }^{31}$ M. Amien Rais, Membangun Politik Adilubung: Membumikan Taubid Sosial Menegakkan Amar Ma'ruf Nahi Mungkar (Bandung: Zaman Wacana Mulya, 1998), hlm. 115.

${ }^{32} \mathrm{M}$. Amien Rais, "Dalam Istilah Politiknya Disebut Political Standstill", dalam Salim (ed.), Tujub Mesin, hlm. 35.

${ }^{33}$ Mantan tahanan politik pada masa Orde Baru. 
penggarapan dan intervensi penguasa kepada segala bentuk mekanisme sosial yang berkembang di masyarakat akan menjadi nilai tabu, (3) umat Islam akan diuntungkan karena ada parpol yang concern memperjuangkan aspirasinya. Adapun pengaruh negatifnya ialah, (1) arus keterbukaan bila berkembang menjadi anarki akan menghancurkan jalannya reformasi dan nilai toleransi antar dan inter umat beragama, (2) karena keragaman pandangan politik Islam antar partai Islam, maka akan menyebabkan beragamnya pola dan perilaku politik masing-masing partai Islam sehingga antar partai Islam sendiri (dan dengan partai lainnya) sangat mungkin terjalin konflik, dan (3) kecurigaan ideologis kelompok akan dihembuskan oleh kelompok anti Islam dan Islam phobia dalam usaha membuat citra negatif terhadap partai Islam. ${ }^{34}$

Di samping itu, Abdurrahman Wahid, tokoh moderat yang sering memperjuangkan Islam kultural, ${ }^{35}$ sebelumnya tidak pernah menyatakan akan memperjuangkan Islam secara formalistik melalui partai politik, bahkan NU (Nahdlatul Ulama) sebagai tempatnya dalam memperjuangkan Islam kultural pernah keluar dari politik praktis pada tahun 1984, yang dikenal dengan sebutan "kembali ke khittah 1926". "Namun pada era reformasi, ia mendirikan PKB (Partai Kebangkitan Bangsa) bersama tokoh-tokoh NU lainnya. ${ }^{37}$ Dalam salah satu acara partai, ia mengatakan: "kini, saatnya kita melakukan pembalasan."38 Kalimat itu kemudian dimaknai sebagai gambaran luapan pemberontakan terhadap struktur dan kultur yang tidak adil, non-demokratis dan manipulatif, yang sering

${ }^{34}$ A.M. Fatwa, "Satu Islam Banyak Partai", dalam Abdul Mu'nim DZ (ed.), Islam di Tengah Arus Transisi (Jakarta: Kompas, 2000), hlm. 124-125.

${ }^{35}$ Kajian terkini tentang Abdurrahman Wahid, baca Greg Barton, Abdurrabman Wabid: Muslim Democrat, Indonesian President (A view from the Inside) (Sydney: University of New South Wales, 2002).

${ }^{36}$ Lihat H. Rozikin Daman, Membidik NU: Dilema Percaturan Politik NU Pasca Khittah (Yogyakarta: Gama Media, 2001), hlm. 180-196; Agus Sudibyo, "Dinamika Corak Berpolitik Elite NU: Tarik-Menarik yang Tak Kunjung Usai," Tashwirul Afkar, No. 9, 2000, hlm. 80; Robin Bush, "Redefining "Political Islam" in Indonesia: Nahdlatul Ulama and Khittah '26", Studia Islamika, Vol. 7, No. 2, 2000, hlm. 64-73.

${ }^{37}$ Lihat misalnya, Matori Abdul Jalil, "PKB Tidak Akan Mengeksploitasi Emosi Umat Islam", dalam Salim (ed.), Tujuh Mesin, hlm. 220-228.

${ }^{38}$ Ahmad Baehaqi, Islam dan Nasionalisme (Analisis Terhadap Nasionalisme Partai Kebangkitan Bangsa) Skripsi S. Ag. Fakultas Syari'ah Jurusan Jinayah al-Siyāsah, IAIN Sunan Kalijaga Yogyakarta, 2001, hlm. 67. 
menimbulkan ketertindasan dan penderitaan warga NU, yang rata-rata wong cilik (rakyat kecil). ${ }^{39}$

Sementara itu, pandangan yang tidak mendukung berdirinya partai Islam antara lain dikemukakan oleh Kuntowijoyo. Menurutnya ada enam alasan untuk tidak mendirikan partai politik Islam. Pertama, terhentinya mobilitas sosial umat Islam. Alasannya, bahwa ada dominasi kaum santri dalam dunia profesi, budaya, dan akademis pada tahun 1990-an. Mobilitas sosial vertikal itu akan terhenti bila kaum santri kembali berpolitik. Kedua, disintegrasi umat. Alasan ini dengan asumsi bahwa masing-masing partai politik Islam akan mencari indentitas politiknya, sehingga yang menonjol adalah perbedaan, bukan persamaan. Ketiga, umat menjadi miopis. Alasan ini dilandaskan pada kepentingan yang berbeda antara politik dan agama. Politik berorientasi pada kekuasaan jangka pendek, sedangkan agama memiliki kepentingan jangka panjang serta tidak hanya untuk kekuasaan, tetapi aspek-aspek lain dalam kehidupan manusia. Keempat, pemiskinan. Alasan ini didasarkan pada keyakinan bahwa agama merupakan sinar tunggal yang memancar, tetapi dalam masyarakat ia mampu mengurai menjadi banyak sinar; dakwah, kehidupan sosial, kebudayaan, sistem pengetahuan, iptek, filsafat, mitos, politik, SDM, mentalitas, dan sebagainya. Mendirikan partai politik berarti akan membunuh potensipotensi itu untuk berkembang. Kelima, runtuhnya proliferasi yang selama ini telah terbentuk. Dengan berdirinya partai politik Islam, maka penghargaan tertinggi umat nanti diberikan pada tokoh politik dan akan bisa timbul kemungkinan melupakan atau menghilangkan gambaran bahwa tokoh umat itu bisa saja dari berbagai bidang, seperti usahawan, seniman, atau intelektual. Keenam, alienasi generasi muda. Alasan ini dengan asumsi bahwa generasi muda Islam sekarang tidak lagi sektarian. Dengan kata lain, politik mereka tidak lagi terikat pada mobilitas geografis dan generasi mengambang. Yang dimaksud mobilitas geografis ialah perpindahan tempat seseorang dalam kehidupan sosialnya karena pendidikan, pekerjaan, dan kedinasan. Adapun generasi mengambang ialah generasi muda yang

39Jalil, "PKB Tidak Akan”, hlm. 220. 
tidak lagi menghayati aliran-aliran keagamaan, sehingga bisa menerima aliran apa saja asalkan Islam. ${ }^{40}$

Azyumardi Azra juga tidak setuju dengan berdirinya partai-partai politik Islam. Azra berpendapat bahwa ide pendirian partai-partai Islam lebih banyak didukung keinginan elit politik Muslim untuk mendapatkan kekuasaan dari pada alasan-alasan keagamaan. ${ }^{41}$ Pendapat ini tampaknya tidak keliru, sebab banyak partai yang didirikan oleh umat Islam dengan lebih mengandalkan tokoh-tokoh politik dari pada program partai. ${ }^{42}$

Adapun alasan lain mengenai adanya pihak yang tidak setuju dengan berdirinya partai-partai di kalangan Islam adalah karena ada tanda-tanda untuk mendirikan negara Islam. ${ }^{43}$ Inilah salah satu isu yang paling ditakutkan dengan banyaknya partai yang bangkit dari kalangan Islam. Perjuangan untuk mendirikan negara Islam menjadi sangat terkristal, sebab $85 \%$ penduduk Indonesia beragama Islam. Jadi, dapat dibayangkan jika partai-partai Islam kemudian ingin mendirikan negara Islam, maka hal tersebut akan mudah untuk direalisasikan. Namun setelah melihat

${ }^{40}$ Kuntowijoyo, "Enam Alasan untuk Tidak Mendirikan Parpol Islam", dalam Hassan et.al. (ed.), Memilih Partai Islam, hlm. 191-196; idem, Muslim Tanpa Masjid: Esai-Esai Agama, Budaya, dan Politik dalam Bingkai Strukturalisme Transendental, c. 2 (Bandung: Mizan, 2001), hlm. 326-332.

${ }^{41}$ Azyumardi Azra, "The Islamic Factor in Post-Soeharto Indonesia”, Profetika Jurnal Studi Islam, Vol. 1, No. 2, Juli 1999, hlm. 157; idem, "Kian Meluas, Penggunaan Simbol Agama", Tashwirul Afkar, No. 2, 1999, hlm. 60; idem, "Faktor Islam di Indonesia PascaSoeharto", dalam Chris Manning dan Peter Van Diermen (ed.), Indonesia di Tengab Transisi: Aspek-Aspek Sosial Reformasi dan Krisis, terj. Landung Simatupang et. al. (Yogyakarta: LKiS, 2000), hlm. 377.

${ }^{42}$ Dalam PKB misalnya, posisi Wahid selalu berada "di depan" atau "di belakang" partai. Lihat Ulil Abshar-Abdalla, "Partai, Civic Education dan Wilayah "Netral Politik", Tashurirul Afkar, No. 4, 1999, hlm. 49. Di PAN (Partai Amanat Nasional) sendiri, karisma Amien Rais mampu "memikat" para pendukung untuk memilih partai ini. Lihat Eep Saefulloh Fatah, "Saya Kira, Popularitas Amien Luar Biasa", dalam Salim (ed.), Tujuh Mesin, hlm. 43-51. Selain dua partai tersebut, banyak tokoh Islam yang sangat disegani di kancah politik Indonesia terlibat dalam mendirikan partai, seperti Deliar Noer, Yusril Ihza Mahendra, Ahmad Sumargono, Hartono Mardjono, Salahuddin Wahid (adik Abdurrahaman Wahid), dan beberapa kiai di Jawa yang menggagas partai setelah tidak puas dengan pendirian PKB, yaitu Partai SUNI (Partai Solidaritas Uni Indonesia) pimpinan Abu Hasan, PKU (Partai Kebangkitan Ummat) pimpinan Salahuddin Wahid, dan PNU (Partai Nahdlatul Ummah) pimpinan Syukron Makmun.

${ }^{43}$ Baca misalnya, Nur Iskandar al-Barsani, "Langkah Mundur; Menggunakan Asas Sektarian", Tashuirul Afkar, No. 4, 1999, hlm. 55. 
beberapa partai yang didirikan oleh umat Islam, tampaknya tidak ada indikasi ke arah itu.

Munculnya gejala fundamentalisme Islam juga ikut menjadi kekhawatiran di balik berdirinya partai-partai Islam. ${ }^{44}$ Karena itu, tidak sedikit tokoh partai politik Islam menegaskan bahwa partai mereka terbuka dan inklusif. Dengan kata lain, mereka tidak ingin menampakkan wajah Islam fundamentalis dalam diri partai. Beberapa partai yang didirikan oleh kalangan Islam bahkan melandaskan asas partainya pada Pancasila, bukan pada Islam.

Dengan demikian, bangkitnya partai-partai di kalangan umat Islam, terlepas dari pro dan kontra, membuktikan bahwa kekuatan "Islam politik" di Indonesia pada hakikatnya selalu ada pada tokoh-tokoh penting Islam. Sehubungan dengan itu, tokoh-tokoh tersebut ketika mendirikan partai politik sangat didukung oleh situasi politik yang ada. Dengan bahasa lain, dari pada suara umat Islam digunakan oleh "kelompok lain", tentunya lebih baik jika disalurkan kepada partai sendiri.

\section{Partai Islam dalam Pemilu 1999}

Menghadapi pemilu 1999, umat Islam sekali lagi kembali dibingungkan oleh banyaknya partai yang bernasabkan kepada Islam. Ada yang mengklaim dirinya sebagai partai Islam dan ada yang bukan, tetapi partai tersebut berbasiskan mayoritas umat Islam. Dalam hal ini memang ditemui beragam pandangan mengenai partai Islam. Ada dua unsur yang menjadi tanda sebuah. partai dapat disebut "Islami", yakni (1) dalam dokumentasi partai secara resmi memakai Islam sebagai dasar ideologi, sebagaimana kebanyakan partai Islam, dan (2) dalam kasus tertentu partaipartai Islam tetap memakai Pancasila sebagai dasar ideologi tetapi pada saat yang sama menggunakan simbol-simbol lain yang berhubungan dengan Islam. ${ }^{45}$

${ }^{44}$ Lihat misalnya Jamhari, "Islamic Political Parties: Threats or Prospect?", dalam Forrester (ed.), Post-Soeharto Indonesia, hlm. 186.

${ }^{45}$ Azra, "Faktor Islam", hlm. 376. Lihat juga M. Imdadun Rahmat, et.al., "PartaiPartai Islam: Trasformasi Gerakan Islam dan Ruang Demokrasi”, dalam Tashwirul Afkar, No. 4, 1999, hlm. 4-15. 
Dalam pemilu 1999, partai-partai yang menggunakan asas Islam sebanyak 13 partai atau 27,08\% dari 48 partai yang ikut pemilu, yaitu PK (Partai Keadilan), PSII (Partai Syarikat Islam Indonesia), PBB (Partai Bulan Bintang), PNU (Partai Nahdlatul Ummah), PUI (Partai Umat Islam), PKU (Partai Kebangkitan Ummat), Partai KAMI (Partai Kebangkitan Muslim Indonesia), PP (Partai Persatuan), PMB (Partai Masyumi Baru), PPIIM (Partai Politik Islam Indonesia Masyumi), PAY (Partai Abul Yatama), PSII (Partai Syarikat Islam Indonesia) 1905, dan PPP (Partai Persatuan Pembangunan). Pada pemilu kali ini, dari sekian banyak partai, hanya tujuh partai yang mendapat kursi di parlemen yakni PK 7 kursi, PPP 58 kursi, PBB 13 kursi, PNU 5 kursi, PKU, PPIIM, PSII, dan PP masing-masing satu kursi. Adapun partai politik yang menggunakan asas Pancasila namun menggunakan simbol-simbol Islam sebanyak 7 partai atau 14,58\% yakni PKB (Partai Kebangkitan Bangsa), PAN (Partai Amanat Nasional), PCD (Partai Cinta Damai), Partai SUNI (Partai Solidaritas Uni Indonesia), PUMI (Partai Umat Muslimin Indonesia), PID (Partai Indonesia Damai), dan PIB (Partai Indonesia Baru). Dalam pemilu kali ini PKB memperoleh 51 kursi dan PAN 34 kursi.

Dengan demikian, kekuatan partai Islam baik yang menggunakan asas maupun simbol Islam pada pemilu 1999 sebanyak 21 partai atau 40,5\%. Namun setelah pemilu, partai-partai yang mendapat suara secara keseluruhan sebanyak 12 partai. Jumlah tersebut menunjukkan bahwa kekuatan partai-partai dari kalangan Islam mencapai 172 kursi dari 462 kursi yang diperebutkan. Dengan kata lain, kekuatan "Islam politik" dari partai-partai yang menggunakan asas maupun simbol Islam mencapai $41,66 \%$.

Secara garis besar pada pemilu 1999, partai yang menggunakan asas Islam memperoleh 87 kursi atau 50,58\% dari 172 kursi kekuatan "Islam politik", sedangkan partai yang tidak menggunakan asas Islam (hanya menggunakan simbol Islam, yaitu PAN dan PKB) jika disatukan menjadi 85 kursi atau 49,42\%. Hanya saja, kekuatan Islam politik yang berasaskan Islam tersebar pada 8 partai, sedangkan yang menggunakan simbol Islam hanya tersebar pada PKB dan PAN.

Sementara itu, ada fenomena ketidakinginan partai-partai Islam untuk bersatu. Dari awal sudah tampak bahwa partai-partai Islam tidak 
mengalami perubahan yang signifikan. Hal ini terlihat dari masih adanya partai-partai politik Islam aliran, seperti yang berasal dari NU yaitu $\mathrm{PKB}$, PKU, PNU, dan Partai SUNI. Demikian juga terdapat tiga partai penerus Masyumi, yaitu PBB, PPIIM, dan PMB. Sedangkan yang berasal dari PSII ada dua partai yaitu PSII dan PSII 1905.

Sedangkan partai-partai Islam lainnya seperti PAN, PUI, PK dan PPP merupakan partai Islam yang tampaknya tidak punya kesinambungan historis secara langsung dengan partai politik pada masa Orde Lama. Namun demikian, para pendukung partai-partai tersebut dapat dikatakan berasal dari organisasi keislaman, misalnya Muhammadiyah, PII (Pelajar Islam Indonsia), dan HMI (Himpunan Mahasiswa Islam). Selain itu terdapat juga partai yang lahir akibat kekecewaan terhadap hasil keputusan politik partai sebelumnya, seperti PP (Partai Persatuan) pimpinan Jaelani Naro yang lahir dari PPP akibat kekecewaan atas hasil Muktamar tahun $1988 .{ }^{46}$

Tampaknya elit politik Islam memang selalu lebih mengedepankan fragmentasi dari pada persatuan. Hal ini dapat dilihat dari pembentukan fraksi di DPR (Dewan Perwakilan Rakyat) yang memperlihatkan partaipartai tersebut tidak bersatu. PKB misalnya membentuk FKB (Fraksi Kebangkitan Bangsa) yang berdiri sendiri dan tidak melakukan fusi dengan partai-partai dari NU lainnya (PNU dan PKU). Begitu juga PBB membentuk FPBB (Fraksi Partai Bulan Bintang), tidak bersatu dengan dengan partai eks-Masyumi lainnya, yaitu PPIIM dan PMB. Sedangkan PP meski berasaskan Islam, tetapi tidak masuk ke dalam FPP (Fraksi Persatuan Pembangunan), melainkan bergabung dengan FKKI (Fraksi Kesatuan Kebangsaan Indonesia) yang didominasi oleh partai-partai sekuler.

Dari kenyataan tersebut dapat dicermati bahwa di kalangan Islam, akar perbedaan ketika mendirikan partai juga membawa dampak pada

${ }^{46}$ Julia I Suryakusuma, et.al., Almanak Parpol Indonesia (Jakarta: API, 2000), hlm. 438; Politik kekecewaaan ini ternyata tidak hanya melanda partai-partai di kalangan umat Islam. Di Partai Golkar pun terjadi hal yang serupa yaitu munculnya PKP yang dilandasi oleh ketidakpuasan kubu Edi Sudrajat terhadap hasil Musyawarah Nasional Luar Biasa tanggal 9-11 Juli 1998 dengan kepemimpinan Akbar Tanjung. Demikian juga lahirnya Partai MKGR diawali oleh ketidakpuasan terhadap Partai Golkar yang menurut mereka tidak lagi aspiratif terhadap rakyat: 
ketidakinginan mereka untuk bersatu dalam parlemen. Di antara fraksi partai-partai Islam tersebut, hanya PK dan PAN yang tidak punya "politik kekecewaan" dan kemudian bergabung dengan nama Fraksi Reformasi. ${ }^{47}$

Partai-partai dari kalangan Islam ternyata belum mampu memenangkan pemilu 1999 kendati sebagian mereka memakai asas Islam dan sebagian lainnya memakai simbol Islam. Dengan demikian, hasil pemilu 1999 merupakan kemenangan kelompok sekuler yang diwakili oleh PDI-P (Partai Demokrasi Indonesia-Perjuangan) pimpinan Megawati Soekarnoputri. Setidaknya ada lima faktor yang menyebabkan kemenangan partai ini dalam pemilu. Pertama, PDI-P dan sosok Megawati merupakan antitesa dari partai rezim Orde Baru (Golkar) dan sosok Soeharto. Kedua, PDI-P adalah partai yang paling siap mengakomodasi euphoria demokrasi sejak lengsenya Soeharto tanggal 21 Mei 1998. Ketiga, tingkat partisipasi politik pemilih dalam Pemilu 1999 masih dalam tahap parokial, mudah dimobilisasi, sama seperti pemilu-pemilu sebelumnya. Keempat, PDI-P merupakan salah satu partai yang dimanjakan oleh pemberitaan media cetak dan elektronik. Serta kelima, PDI-P adalah partai yang tampaknya mempunyai dana cukup besar. ${ }^{48}$

Sementara itu penyebab tidak menangnya partai-partai Islam pada pemilu tersebut dilatarbelakangi oleh beberapa hal: Pertama, waktu yang tidak lama untuk membangun jaringan partai sampai ke akar rumput (rakyat kecil). Banyak partai Islam yang dibangun oleh kepentingan sesaat elit politik sehingga ketika pemilu mereka lebih mengandalkan tokoh dari pada program partai. Kedua, isu-isu yang diangkat oleh partai-partai Islam cenderung lebih dikonsumsi oleh wilayah pemilih yang tinggal di perkotaan. Artinya, para pemilih partai Islam lebih banyak berada di perkotaan dari pada pedesaan. Hanya PKB yang paling banyak mendapat suara dari pemilih pedesaan di Jawa Timur. Hampir 52,7\% (7.034.707)

\footnotetext{
${ }^{47}$ Nama "Fraksi Reformasi" adalah usulan dari Partai Keadilan yang disetujui PAN. Lihat Iman Nugraha et.al., Sikap Kami: Kumpulan Seruan, Pernyataan Sikap, Bayanat dan Pidato Politik DPP Partai Keadilan (Jakarta: HUMAS DPP Partai Keadilan, 2001), hlm. 84.

${ }^{48}$ Fadhli Zon, "Pemilu 1999: Kemenangan Status Quo Baru?", dalam Gouzali Saydam (ed.), Dari Balik Suara ke Masa Depan Indonesia: Potret Konflik Politik Pasca Pemilu dan Nasib Reformasi (Jakarta: RajaGrafindo Persada, 1999), hlm. 69-71. Lihat juga Ahmad Suhelmi, Soekarno Versus Natsir: Kemenangan Barisan Megawati Reinkarnasi Nasionalis Sekuler (Jakarta: Darul Falah, 1999), hlm. 112-114.
} 
suara PKB diperoleh dari kawasan yang merupakan basis NU tersebut. Sedangkan partai-partai lain seperti PAN lebih banyak dipilih oleh warga perkotaan. ${ }^{49}$ Ketiga, kebingungan umat ketika ingin memilih partai-partai Islam. Banyaknya partai menjadikan suara umat Islam terdistribusi ke beberapa partai yang tentu saja sangat merugikan kekuatan umat Islam sendiri, sebab perhitungan kursi di parlemen didasarkan pada jumlah pemilih partai. Keempat, sebagai akibat dari faktor di atas, maka umat Islam ternyata lebih banyak memilih partai dengan berlandaskan pada asas dan pimpinan partai.

\section{E. Nilai-nilai Islam dalam Kehidupan Sosial Politik}

Saat ini jumlah penduduk Muslim sekitar $86 \%$ dari jumlah keseluruhan rakyat Indonesia. ${ }^{50}$ Jumlah tersebut dapat diklasifikasikan kepada dua bagian, yaitu kelompok Islam ortodok (santri) dan sinkretis (abangan). Kelompok Islam ortodok (santri) umumnya terdapat di kalangan pesantren di kawasan pedesaan. Di saat yang sama, wilayah pedesaan di Indonesia masih lebih mendominasi dibandingkan dengan wilayah perkotaan. Isu-isu yang berkembang di wilayah pedesaan lebih banyak direspon dengan melihat "siapa" yang mengatakan bukan "apa" yang dikatakan. Di sinilah muncul kelompok ulama yang membidangi pertumbuhan pesantren. Jika suatu pendapat dikeluarkan oleh ulama, maka semua pengikutnya akan mematuhi tanpa ada bantahan. Dengan demikian, jarang terjadi proses rasionalisasi, yang ada hanya hubungan emosi antara ulama dan santri serta dengan masyarakat setempat. ${ }^{51}$ Sehingga, ketika ada

${ }^{49}$ Menurut hasil riset LP3ES, mayoritas pemilih PAN (66\%) adalah mereka yang tinggal di perkotaan, padahal mayoritas pemilih tinggal di desa. Lihat lebih lanjut Muhamad Najib, "Evaluasi dan Analisa Hasil Pemilu", http://www.e-amienrais.com/ target.asp?judul=pemilu, 23 April 2002.

${ }^{50} \mathrm{R}$. William Liddle dan Saiful Mujani, "The Islamic Challenge to Democratic Consolidation in Indonesia (Makalah disampaikan dalam International Conference "The Challenge of Democracy in Muslim Countries" di Radisson Yogya Plaza Hotel, Yogyakarta, 25 Mei 2002), hlm. 2.

51Penulis sempat mewawancarai beberapa mahasiswa di Yogyakarta yang tinggal di pesantren. Mereka cenderung "dipaksa” untuk memilih partai tertentu, yang dalam beberapa hal, tegas mereka, kiai memegang peranan penting dalam memobilisasi suara untuk partai tersebut. 
agenda politik tertentu, yang pertama kali didekati adalah para ulama setempat. $^{52}$

Hal di atas berbeda dengan kelompok perkotaan yang jarang memperhatikan "siapa" yang mengatakan, tetapi "apa" dan "mengapa" sesuatu dikatakan, sehingga diperlukan proses rasionalisasi dan bukan figur sebagaimana yang terjadi di pedesaan. Untuk memahami "apa" dan "mengapa" tersebut, maka di wilayah perkotaan muncullah kemudian gerakan Islam atau kelompok jamaah diskusi Islam.

Mengikuti perkembangan zaman, kelompok santri ini kemudian merambah ke wilayah perkotaan. Proses ini terjadi pada 1990-an dengan sebutan "santrinisasi" (santrinization), yang ditandai dengan munculnya sekolah-sekolah elite Muslim yang dikenal sebagai "sekolah Islam"." 53 Sekolah tersebut menawarkan sistem pendidikan yang mengajarkan ilmuilmu keislaman dan ilmu umum sekaligus. Dengan kata lain, sekolah model ini menawarkan sistem pendidikan yang diterapkan di pesantren dengan mengasramakan para murid serta belajar Islam sebagaimana layaknya di pesantren. Pada saat yang sama, para murid diajarkan pula ilmu-ilmu yang diajarkan di sekolah dengan sistem pendidikan umum.

Selain proses di atas, dapat dikemukankan pula bahwa dengan dikirimnya beberapa mahasiswa ke Barat untuk mempelajari Islam, juga ikut mewarnai kehidupan umat Islam di Indonesia. Hampir semua pemikir Islam di Indonesia pernah belajar Islam di Barat dan di saat yang sama juga pernah mengecap pendidikan Islam di pesantren. ${ }^{54}$ Dalam hal ini, ada

${ }^{52}$ Lihat misalnya Zaenal Ma'arif, "Agama, Ekonomi dan Politik: Peranan Ulama dan Pengusaha dalam Kemenangan Partai Persatuan Pembangunan (PPP) di Jepara pada Pemilu 1999", Profetika, Vol. 3, No. 2 Juli, 2001, hlm. 170-192.

${ }^{53}$ Azyumardi Azra, Pendidikan Islam: Tradisi dan Modernisasi Menuju Milenium Baru (Jakarta: Logos, 1999), hlm. 73; idem , "The Rise of Muslim Elite Schools: A New Pattern of "Santrinization": in Indonesia", Al-Jämi'ah, No. 64, 1999, hlm. 67.

${ }^{54}$ Salah seorang alumni Barat yaitu Yudian W. Asmin mengemukakan bahwa orang sering melupakan fakta bahwa pesantren sebagai sekolah menengah yang berspesialisasi dalam pendidikan agama merupakan lembaga pendidikan Islam berkelas di Indonesia. Dosen-dosen IAIN yang mampu membaca kitab berbahasa Arab pada umumnya adalah lulusan pesantren baik tradisional maupun modern... Ada bukti lain bahwa lulusan pendidikan Barat tetap unggul dalam pemikiran keislaman dibandingkan doktor-doktor atau master-master dari Barat yang tadinya tidak sempat bersekolah di pesantren. Lihat Yudian W. Asmin, "Posisi Alumni Islamic Studies dalam Percaturan Pemikiran Islam 
pendapat bahwa pada akhir 80 -an, mulai banyak generasi muda dari kalangan NU yang belajar ke Barat seiring dengan berbagai kebijakan pemerintah yang mengirim para pemuda Muslim belajar ke luar negeri. ${ }^{55}$

Pada gilirannya, program ini memberikan pengaruh yang cukup signifikan terhadap proses keberagamaan umat Islam di Indonesia, tidak terkecuali dalam bidang politik. Dalam hal ini, Howard M. Federspiel mengatakan:

Indonesia Muslim groups represent a typical anomaly found in several other part other Muslim world, in that they usually like Americans, thinks American and American education, yet are highly dissatisfied with American foreign policy and regard that policy as aimed at harming important Muslim interest in the world. ${ }^{56}$

Oleh karena itu tidak mengherankan bila dalam kancah Islam politik di Indonesia, warna-warni pemikiran dari Barat ikut memberi kesan tersendiri kepada tokoh-tokoh Islam politik. Mereka sering mencontohkan Amerika sebagai negara yang paling demokratis di dunia. Ringkasnya, mereka sering think like American. Pada sisi lain, tidak sedikit gerakan Islam di Indonesia yang tidak menyukai Amerika dan biasanya muncul dari kelompok-kelompok Islam yang terwadahi dalam gerakan atau partai politik yang berasal dari kalangan Islam perkotaan.

Dengan demikian, dapat dipahami jika kemudian tokoh-tokoh "Islam politik" berasal dari kelompok santri yang memiliki ikatan kultural dengan masyarakat setempat. Ini menunjukkan basis Islam politik tidak dapat dipisahkan dari keragaman yang muncul dalam Islam kultural. Dalam hal ini, tidak terlalu berlebihan jika ada pendapat yang menyebutkan bahwa dalam perkembangannya Indonesia sedang menjurus menjadi sebuah "negara santri" yaitu nilai-nilai asasi Pancasila akan mengejawantah dan mengaktualisasi diri melalui dan dalam bentuk nilai-nilai kesantrian yang kosmopolit dan nasional. ${ }^{57}$ Kecuali itu, munculnya tiga tokoh dari kalangan

Indonesia Abad XXI", dalam Yudian W. Asmin (ed.), Pengalaman Belajar Islam di Kanada (Yogyakarta: Titian Ilahi Press, 1997), hlm. 385.

${ }^{55}$ Rumadi, “Jejak-Jejak Liberalisme NU”, Tashwirul Afkar, No. 9, 2000, hlm. 16.

${ }^{56}$ Howard M. Federspiel, "Indonesia, Islam, and American Policy", (Makalah dipublikasikan dan diberikan kepada penulis via e-mail, 10 Maret 2002), hlm. 9.

${ }^{57}$ Nurcholish Madjid, Tradisi Islam: Peran dan Fungsinya dalam Pembangunan (Jakarta: Paramadina, 1997), hlm. 61. 
Islam yaitu Amien Rais sebagai ketua MPR (Majlis Permusyawaratan Rakyat), Akbar Tanjung sebagai Ketua DPR dan Abdurrahman Wahid sebagai Presiden, ikut mendukung tesis "negara santri" tersebut. Hajriyanto Y Thohari mengemukakan bahwa setidaknya ada dua alasan mengenai keberadaan tiga tokoh tersebut yaitu, (1) ketiganya pernah dan atau masih menjadi pimpinan puncak tiga gerakan Islam; Muhammadiyah, HMI dan NU, (2) meskipun membangun basis kepemimpinan dari gerakan Islam, bahkan gerakan Islam yang sangat tua dan berpengaruh, tetapi ketiga tokoh ini kemudian memimpin partai-partai politik yang pluralis, sangat terbuka dan non-sektarian yaitu PAN, Partai Golkar dan PKB. ${ }^{58}$

Meskipun demikian, masih perlu dikaji lebih lanjut mengenai konsistensi mereka, sebab beberapa peristiwa politik yang muncul kemudian memperlihatkan bahwa ketiga tokoh politik tersebut tidak dapat dipisahkan dari partai dan organisasi mereka. PAN selalu dikaitkan dengan aktivitas Amien Rais dan organisasi yang pernah dipimpinnya yaitu Muhammadiyah. Partai Golkar juga dikaitkan dengan keberadaan Akbar Tanjung dan organisasi HMI melalui KAHMI (Keluarga Alumni Himpunan Mahasiswa Indonesia). Demikian juga PKB tidak dapat memutuskan hubungan yang kongkrit dengan NU dan Abdurrahman Wahid. ${ }^{59}$

Dari penjelasan di atas, muncul beberapa pertanyaan yang sangat signifikan yakni, (1) perlukah ulama terlibat dalam politik praktis? (2) apakah umat Islam akan beruntung jika kekuatan Islam kultural dibawa ke Islam politik? (3) apakah kebangkitan Islam mengharuskan bersatunya Islam politik dan Islam kultural? Untuk menjawab persoalan tersebut dapat dilihat dari adanya polarisasi yang sangat beragam pada anggota DPR yang berasal dari partai-partai Islam. Harus diakui, paling tidak kekuatan Islam politik di DPR mencapai 405 orang (81\%) dari jumlah keseluruhan.

${ }^{58}$ Hajriyanto Y. Thohari, “"Negara Santri”: Menengok Tesis Cak Nur”, dalam Mu'nim DZ (ed.), Islam Di Tengah, hlm. 26.

${ }^{59}$ Agus Sudibyo mencatat bahwa elit PKB masih sering terjebak pada simbol-simbol supranatural dan mitos-mitos kewalian seorang kiai, termasuk terhadap Abdurrahman Wahid. Ia disebut setingkat "wali" dan diberkahi dengan ilmu ladunni yang memiliki kemampuan istimewa dan membedakannya dengan orang lain. Orang-orang yang mengkritik Abdurrahman Wahid dinilai salah karena dianggap tidak dapat memahami jalan pikiran beliau. Lihat Sudibyo, "Dinamika Corak", hlm. 77. 
Adapun kekuatan politik non-Islam sejumlah 95 orang (19\%). Dari sejumlah 405 orang tersebut dapat dipetakan dalam kategori yang lebih genuine, yakni berdasarkan organisasi dari kalangan umat Islam seperti Muhammadiyah, NU, PII (Pelajar Islam Indonesia), HMI, PMII (Pergerakan Mahasiswa Islam Indonesia), DDII (Dewan Dakwah Islamiyah Indonesia), KISDI (Komite Indonesia untuk Solidaritas Dunia Islam), dan ICMI (Ikatan Cendekiawan Muslim se-Indonesia). ${ }^{60}$

Hasil pelacakan terhadap anggota DPR menunjukkan banyaknya warga NU di lembaga legislatif ini, meski disebut telah kembali ke khittah 1926. Data ini bisa dimaknai bahwa tidak ada indikasi kalangan NU memperjuangkan Islam secara kultural. Di samping itu, meski PKB disebut sebagai partai inklusif, ternyata anggota parlemennya berasal dari kalangan NU dan organisasi yang menjadi underbaownya yaitu PMII dan IPNU (Ikatan Pelajar Nahdlatul Ulama). Bahkan bagian terbesar basis pemilih dan yang dipilih berasal dari Jawa Timur, yang merupakan basis NU (26 orang). Sehubungan dengan itu, ternyata Islam politik lebih banyak diperjuangan oleh kalangan Islam tradisional atau Islam santri, yang terlihat dari besarnya jumlah kalangan Islam tradisional yang diwakili NU dan PMII di parlemen. Selain itu, kelompok santri ternyata tidak memasukkan kelompok lain dalam perjuangan mereka. Hal ini dibuktikan oleh PKB yang tidak mempunyai satupun anggota legislatif non-Muslim, demikian juga dari garis pemikiran yang berseberangan dengan mereka, seperti kelompok modernis.

Kekuatan Islam politik yang diperjuangkan oleh kelompok Islam perkotaan atau Islam modernis dapat dikatakan "masih kalah" dibandingkan dengan Islam tradisional. Kelompok Islam modernis berjumlah 65 orang yang berasal dari organisasi Muhammadiyah, HMI dan ICMI, yang terdistribusikan ke dalam PAN dan Partai Golkar. Dalam Partai Golkar sendiri masih kuat dominasi HMI dalam mencetak kadernya untuk duduk di parlemen, di samping HMI dan ICMI sendiri merupakan

60Data ini dirujuk pada Daniel Dhakidae et.al. (ed.), Wajab Dewan Pervakilan Rakyat Republik Indonesia Pemiliban Umum 1999 (Jakarta: Kompas, 2000). 
dua organisasi yang memiliki hubungan yang sangat dekat dengan Partai Golkar. ${ }^{61}$

Sementara itu, kekuatan Islam abangan masih banyak didominasi oleh PDI-P. Dalam sejarahnya, kelompok Islam abangan sering bergabung dengan kelompok nasionalis sekular untuk menolak keinginan menjadikan Islam sebagai asas negara. Disamping itu, jauh sebelum pemilu dilaksanakan, muncul gejala yang menunjukkan bahwa PDI-P pimpinan Megawati melakukan manuver-manuver politik yang terkesan phobia terhadap Islam. Partai ini mengulangi langkah-langkah historis dan kebijakan politik Soekarno dan PNI terhadap Islam politik. ${ }^{62}$ Pada era reformasi, PDI-P tidak merubah strategi perjuangannya dalam hal dominasi kelompok Islam abangan dan non-Muslim. ${ }^{63}$ Hasil pemilu kemudian memberi data bahwa 36,6\% dari 153 anggota DPR yang berasal dari PDI-P adalah non-Muslim. ${ }^{64}$ Adapun selebihnya dapat dikatakan sebagai Islam abangan. ${ }^{65}$

Inilah yang kemudian menimbulkan beberapa respon dari umat Islam, di antaranya MUI (Majlis Ulama Indonesia) mengeluarkan tausiyyah (rekomendasi) untuk mengantisipasi banyaknya calon legislatif non-Muslim dari PDI-P. Tausiyyah ini dikeluarkan pada tanggal 1 Juni 1999 beberapa hari menjelang pelaksanaan pemilu. ${ }^{66}$

${ }^{61}$ Dalam hal ini Nurcholish Madjid mengatakan: "Lingkungan atau environment lain bagi HMI yang bersifat immediate, adalah ICMI. Tidak seperti KAHMI, ICMI bukan kelanjutan langsung dari HMI. Namun, tidak dapat dipungkiri bahwa ICMI, dilihat dari pribadi-pribadi yang terlibat dalam proses pelahirannya maupun mungkin sebagian aspirasinya, sedikit banyak dapat (sekali lagi, "dapat", artinya tidak "harus") menjadi environment perjuangan HMI dalam melaksanakan misinya". Lihat Madjid, Tradisi Islam, hlm. 105.

62Suhelmi, Soekarno Versus Natsir, hlm. 115.

${ }^{63}$ Sebelum pemilu, banyak kalangan yang berpendapat bahwa calon legislatif dari PDI-P didominasi oleh non-Muslim. Lihat Anonim, "Nepotisme Demi Suami Hingga Non-Muslim" Tekad No. 31, 21 Mei-6 Juni 1999, hlm. 16.

${ }^{64} \mathrm{Dari}$ jumlah yang beragama Islam (97 orang), ternyata banyak yang berasal dari partai nasionalis sekular peninggalan Soekarno (PNI).

${ }^{65}$ Lihat Amir Mu'allim, "Bangkitnya Kaum (Islam) Abangan", UNISLA, No. 41, 2000, hlm. 285-286.

${ }^{66}$ Atho Mudzhar, "Studi Hukum Islam dengan Pendekatan Sosiologi" (Pidato Pengukuhan Guru Besar Madya Ilmu Sosiologi Hukum Islam, Disampaikan di Hadapan Rapat Senat Terbuka IAIN Sunan Kalijaga Yogyakarta, 15 September 1999), hlm. 19-21. 
Sementara itu, Ketua Umum MUI Ali Yafie menyatakan bahwa dikeluarkannya amanat atau seruan tersebut adalah dalam rangka kewajiban MUI sebagai pelayan umat dalam bentuk bimbingan keagamaan yang diberikan pada saat diperlukan umat. ${ }^{67}$ Dengan keluarnya rekomendasi tersebut, maka ulama melakukan peran amar ma'rǘf naby munkar. Peran ini meliputi tugas untuk: (a) mendidik umat di bidang agama dan lainnya, (b) melakukan kontrol terhadap masyarakat, (c) memecahkan problem yang berlaku dalam masyarakat, dan (d) menjadi agen perubahan sosial. ${ }^{68}$

Menurut hemat penulis, ada dua alasan ulama untuk melakukan hal tersebut, yaitu alasan normatif dan historis. Alasan normatif didasarkan pada pandangan mengenai tidak ada keterputusan hubungan antara agama dan politik. Oleh karena itu, pada dasarnya agama Islam memberi ruang bagi gerakan politik yang sangat luas. Hanya saja, perdebatan yang muncul adalah mengenai aktualisasi sikap tersebut dalam kehidupan politik. Ulama Indonesia sering terlibat dalam politik karena dilandasi oleh alasan normatif, meskipun selanjutnya mereka juga berbeda pendapat dalam menyikapi situasi tersebut. Alasan historis didasarkan pada fakta bahwa dalam sejarah umat Islam di Indonesia, ulama sering memainkan peranan penting pada setiap momen sejarah bangsa ini. Karena itu, mereka punya ikatan sejarah untuk selalu terlibat di saat keadaan genting bangsa Indonesia. Pada era reformasi, mereka harus selalu mengontrol umat Islam agar tidak dibawa ke arah yang tidak benar. Ulama dan beberapa pimpinan partai Islam khawatir bila dominasi non-Muslim di DPR, nantinya akan mempengaruhi kebijakan pemerintah terhadap umat Islam. ${ }^{69}$

Namun setelah pemilu, Megawati berusaha untuk meyakinkan bahwa partainya akan memperjuangkan nasib umat Islam. Ia menegaskan:

Menanggapi kegelisahan rakyat atas isu Muslim non-Muslim yang sengaja dihembuskan, dengan ini saya nyatakan siapa saja orangnya, selama ia bersedia menjadi wakil rakyat dari fraksi PDI Perjuangan, wajib hukumnya menghormati kenyataan; bahwa mayoritas

${ }^{67}$ Ali Yafie, "MUI Hanya Memberikan Bimbingan Moral", dalam Saydam (ed.), Dari Balik Suara, hlm. 30.

${ }^{68}$ Masykuri Abdillah, "Ulama dan Politik", dalam Mu'nim DZ (ed.), Islam Di Tengah, hlm. 162.

${ }^{69}$ Lihat misalnya Hartono Mardjono, "Caleg Non-Muslim dan Stembus Accord", dalam Saydam (ed.), Dari Balik Suara, hlm. 27. 
penduduk Indonesia adalah pemeluk agama Islam. Oleh karenanya, meningkatkan kualitas kehidupan kaum Muslimin dan Muslimat, merupakan bagian penting yang diwajibkan oleh saya kepada para wakil rakyat dari PDI Perjuangan untuk dicamkan dan dilaksanakan sebagai agenda perjuangan partai. ${ }^{70}$

Kemenangan PDI-P menimbulkan beberapa persoalan, baik dari aspek politik maupun keagamaan. Menurut Harold Crouch, kemenangan PDI-P bukan merupakan kemenangan kelompok modernis, sebab pemilih partai ini tersebar di desa-desa terpencil yang tidak mendengar soal reformasi. Dengan demikian, menurutnya tidak ada kaitan antara kemenangannya dengan nafas reformasi. ${ }^{71}$ Pendapat lain menyebutkan bahwa tidak salah jika dikatakan kemenangan Islam abangan dan sekular ini tidak membawa dampak yang signifikan terhadap jalannya reformasi di Indonesia. ${ }^{72}$

Dengan kata lain, kemenangan Megawati bukanlah karena program reformisnya atau karena ia terlibat dalam proses reformasi. Dibandingkan dengan Amien Rais, ketika reformasi Megawati lebih banyak diam ketimbang menanggapi isu-isu politik yang berkembang. Ia menunggu saat yang tepat untuk tampil di depan publik, sementara pada saat yang sama, kelompok reformis yang dikomandoi kelompok Islam modernis dan Islam tradisionalis tampil dalam situasi perpolitikan yang terjadi. ${ }^{73}$ Sikap diam Megawati ini masih terus terlihat ketika PDI-P seharusnya berkoalisi dengan parti lain, mengingat hasil kemenangan yang hanya 30\%. Namun Megawati memilih untuk tidak melakukannya, meskipun di pihak lain

${ }^{70}$ Megawai Soekamoputri, "Pidato Politik Ketua Umum PDI Perjuangan Dalam Rangka Menyambut Kemenangan Rakyat Pada Pemilu 1999", http:// www. megaforpresident.org/main/pidato.html 26 April 2002.

${ }^{71}$ Harold Crouch, "Kemenangan Mega Bukan Kemenangan Reformis", dalam Saydam (ed.), Dari Balik Suara, hlm. 74.

${ }^{72}$ Baca misalnya Reza Indragiri Amriel, "Siapkah PDI-P Jadi Demokrasi Sejati?", Republika, 1 April 2000; Tim Amanat, "Benarkah Status Quo Baru Dibidani PDI Perjuangan”, dalam dalam Saydam (ed.), Dari Balik Suara, hlm. 79-183.

${ }^{73}$ Mengenai sikap diam ini Megawati menyatakan bahwa hal itu sebagai strateginya dalam menghadapi ketidakjelasan dan keruhnya kondisi perpolitikan yang penuh permainan dan intrik oleh pihak-pihak yang ingin mengaburkan tujuan reformasi yang sesungguhnya. Ia sengaja membiarkan fenomena politik yang berkembang agar semuanya menjadi jelas, baik yang masih berpihak pada status quo maupun yang sebaliknya. Lihat Soekarnoputeri, "Pidato Politik". 
kelompok Islam santri, baik modernis maupun tradisionalis mulai membangun kekuatan bersama untuk membendung barisan Islam abangan tersebut. ${ }^{74}$ Demikian juga ketika reformasi digulirkan, mahasiswa dan umat Islam banyak melakukan aksi demontrasi, berbeda dengan pendukung PDI-P khususnya di Jawa yang sibuk mendirikan posko. ${ }^{75}$

Perdebatan mengenai pencalonan Megawati sebagai presiden, tampaknya paling tidak disebabkan oleh tiga hal. Pertama, kemampuan Megawati diragukan karena ia belum berpengalaman memimpin bangsa atau setidaknya sebuah organisasi. Kedua, sebagai pimpinan PDI-P yang merupakan partai nasionalis sekuler, tampaknya jika terpilih menjadi pemimpin bangsa, maka yang paling dirugikan adalah umat Islam. Ketiga, pertimbangan agama, sampai selesai pemilu 1999, MUI sebagai lembaga resmi belum mengeluarkan fatwa tentang kepemimpinan wanita.

Respon umat Islam berbeda-beda mengenai kapabilitas Megawati sebagai perempuan untuk menjadi presiden. Pada tanggal 17 Juli 1999, mayoritas dari 200 ulama NU yang mengikuti seminar pra-muktamar NU tentang Fiqh al-Nisä menyetujui pemimpin wanita, meski sebagian lainnya menolak. Hasil rumusan tersebut selanjutnya diserahkan kepada Ketua PBNU, K.H. Abdurrahman Wahid dan Matori Abdul Jalil sebagai Ketua Umum $\mathrm{PKB}$, untuk melakukan tawar menawar lebih intens dengan Megawati sebagai Ketua Umum PDI-P. ${ }^{76}$ Bahkan sebelumnya, pada bulan November 1997, hasil Munas (Musyawarah Nasional) ulama NU telah membolehkan wanita untuk tampil dalam kancah politik, yang tentu saja dengan beberapa ketentuan. ${ }^{77}$ Dalam musyawarah tersebut, kalangan ulama tua dikalahkan oleh ulama generasi muda yang disebut-sebut sebagai perinci gagasan Abdurrahman Wahid, yaitu Said Aqil Siradj dan Masdar

${ }^{74}$ Lihat Rusadi Kantaprawira , “Ada Yang Terlupakan oleh PDI-P”, dalam Saydam (ed.), Dari Balik Suara, hlm. 18-21.

${ }^{75}$ Fenomena ini dapat ditemui ketika menjelang reformasi, di tiga kawasan yang sempat penulis lihat yaitu Solo, Magelang dan Yogyakarta. Pengalaman lain yang agak mengkhawatirkan adalah perilaku simpatisan PDI-P yang melakukan kampanye dengan sikap yang tidak ramah.

${ }^{76}$ Mudzhar, "Studi Hukum Islam", hlm. 34-35.

${ }^{77}$ Greg Barton dan Andrée Feillard, "Nahdlatul Ulama, Abdurrahman Wahid and Reformation: What Does NU's November 1997 National Gathering Tell Us?" Studia Islamika, Vol. 6, No. 1, 1999, hlm. 36-37. 
Farid Mas'udi. ${ }^{78}$ Berbeda dengan seminar pra-muktamar yang dimaksudkan untuk menghadapi pencalonan Megawati sebagai presiden pasca Habibie, adapun hasil Munas dipersiapkan sebagai sikap NU menghadapi isu bahwa Siti Hardiyanti Rukmana akan dicalonkan sebagai pengganti Soeharto.

Beberapa tokoh politik kalangan Islam mengemukakan pendapat masing-masing menganai hal ini. Menurut Abdurrahman Wahid, syarat utama seorang calon presiden bukanlah jenis kelaminnya, tetapi kemampuannya untuk menciptakan keadilan, beriman dan bertakwa kepada Allah. ${ }^{79}$ Sedangkan Rais Am Ilyas Ruhiat menyatakan bahwa mayoritas ulama tidak menyetujui seorang wanita menjadi presiden. Adapun tokoh-tokoh NU/PKB yang dekat dengan PDI-P seperti Muhaimin Iskandar dan Said Aqil Siradj, tetap bersikeras bahwa sebagaian besar ulama akan mendukung presiden wanita. ${ }^{80}$ Bagi Nurcholish Madjid yang terpenting ialah figur tersebut mempunyai kemampuan, karena Islam tidak secara jelas mengatur boleh tidaknya seorang wanita menjadi kepala negara, sehingga tidak mempersoalkan apakah presiden dan wakil presiden itu wanita. ${ }^{81}$ Tuty Alawiyah juga mengemukakan hal yang senada, sebab menurutnya bagi wanita yang memang mampu dan kapabel dalam dunia politik, tidak ada sama sekali larangan untuk terlibat dalam politik. Sedangkan bagi yang tidak mampu harus ingat bahwa konsep kewajiban dalam dimensi dinamisnya sangat berkaitan dengan kemampuan. ${ }^{82}$

Pendapat-pendapat di atas menunjukkan bahwa mengenai persoalan tidak adanya larangan bagi wanita untuk menjadi pemimpin, telah didasarkan kepada ajaran Islam. Yang menjadi persoalan sesungguhnya adalah kemampuan wanita tersebut dalam memimpin bangsa. Meskipun demikian, ditegaskan Abdurrahman Wahid bahwa kecil kemungkinan

${ }^{78}$ Lihat Said Aqil Siradj, Islam Kebangsaan: Fiqih Demokratik Kaum Santri (Jakarta: Pustaka Ciganjur 1999), hlm. 7-13.

${ }^{79}$ Mudzhar, "Studi Hukum Islam", hlm. 36.

${ }^{80}$ Bernhard Platzdasch, "Reaksi Islam Terhadap Presiden Wanita", dalam Manning dan Peter Van Diermen (ed.), Indonesia di Tengah Transisi, hlm. 414.

${ }^{81}$ Mudzhar, "Studi Hukum Islam", hlm. 36.

${ }^{82}$ Tuty Alawiyah AS (1999), "Politik dan Wanita: Pendekatan Hak dan Kewajiban", dalam Abu Zahra (ed.), Politik Demi Tuban, hlm. 310-311. 
Megawati menjadi Presiden, karena mayoritas Muslim Indonesia tidak dapat menerima seorang wanita sebagai pemimpin mereka. ${ }^{83}$

Adapun PPP secara langsung tidak mendukung wanita sebagai calon presiden, yang tampaknya lebih didorong oleh alasan politis. Pertama, posisi PPP sebagai kekuatan Islam tentunya harus menandingi PDI-P sebagai kekuatan nasionalis sekular. Kedua, PPP tidak bisa menerima ketidakpekaan PDI-P pada saat memilih calon legislatif. Ketiga, PPP meragukan sikap Megawati secara pribadi terhadap Islam. ${ }^{84} \mathrm{Di}$ samping tiga alasan tersebut, tampaknya yang mengganjal Megawati untuk menjadi presiden adalah sikapnya yang tak mau berkoalisi dengan kalangan Islam.

Tampaknya dukungan dari tokoh-tokoh Islam bukan ditujukan untuk mendukung Megawati menjadi presiden, namun lebih untuk memberikan gambaran pandangan Islam mengenai posisi wanita dalam kancah politik. Dengan demikian, sebenarnya dukungan tokoh tersebut bukan menguntungkan posisi Megawati, akan tetapi mempersulit posisinya, sebab dengan dibolehkannya wanita menjadi pemimpin, maka yang dipertanyakan selanjutnya adalah kemampuan kepemimpinan Megawati.

Sementara itu, kalangan Islam modernis sangat berhati-hati dalam menyikapi masalah tersebut. Kendati pada dasarnya mereka tidak setuju dengan Megawati menjadi presiden, namun mereka menampakkan sikap moderat untuk mengakui bahwa Islam memang tidak melarang seorang wanita untuk menjadi presiden. Mereka mensinyalir bahwa wacana itu digerakkan oleh para sekularis untuk merendahkan partai-partai Islam di mata dunia. ${ }^{85}$ Dengan kata lain, kaum Islam modernis lebih memilih jalur politis dari pada agama untuk menolak Megawati menjadi presiden dan hal ini kemudian mereka buktikan dengan memunculkan "poros tengah" ketika pemilihan presiden dalam Sidang Umum MPR 1999.

Dari uraian mengenai nilai-nilai Islam dalam kehidupan sosial politik di atas, tampak bahwa persoalan internal umat Islam ternyata memberikan dampak yang sangat signifikan terhadap gerak laju Islam politik di

${ }^{83}$ Platzdasch, "Reaksi Islam", hlm. 414. Dalam kenyataannya, penegasan ini telah terbantah oleh sejarah dengan naiknya Megawati sebagai Presiden menggantikan Abdurrahman Wahid.

${ }^{84}$ Ibid., hlm. 415.

${ }^{85}$ Ibid., hlm. 416. 
Indonesia. Perbedaan pendapat mengakibatkan mereka tidak memiliki keinginan bersatu dalam parlemen, sehingga mengakibatkan terpolarisasinya kekuatan Islam politik di DPR. Di samping itu, isu-isu Islam dan non-Islam ternyata masih menjadi pertimbangan tokoh Islam politik dalam memperjuangkan nilai-nilai Islam. Oleh karena itu, mereka sering bersatu untuk menghadang kekuatan-kekuatan non-Islam dan sekular. Dalam hal tertentu, alasan agama tidak menjadi pertimbangan, dan penggunaannya lebih disebabkan oleh situasi politik tertentu. Fenomena ini ternyata tidak merambat pada tingkat bawah, terbukti dengan banyaknya pendukung partai sekular yang berasal dari kelompok Islam pedesaan. Oleh karena itu, mereka tidak ambil perhatian dengan isu-isu yang berkembang dalam alam reformasi. Jadi, dalam hal ini isu elit tidak merambat ke bawah, yang mengakibatkan sulitnya tokoh Islam untuk meyakinkan umat Islam agar tidak memilih partai yang berasal dari kelompok sekular non-Islam.

\section{F. Kesimpulan}

Dalam kajian ini, tentu saja ada beberapa hal yang perlu digarisbawahi. Pertama, pada era reformasi, aktivitas politik umat Islam cenderung masih seperti pada era Orde Lama, yaitu mendirikan partai dan mengangkat isu-isu simbolik. Dalam hal ini, langgam politik yang dimainkan oleh elit politik Islam ternyata tidak memberikan suatu perkembangan politik yang singnifikan bagi umatnya. Akibat perpecahan di kalangan elit politik, "suara" umat Islam terdistribusikan kepada beberapa saluran yang tentu saja dimanfaatkan oleh para elitnya untuk kepentingan diri dan partai. Hingga ketika tulisan ini dibuat, beberapa partai Islam mulai terpecah lebih banyak lagi yang disebabkan oleh tidak adanya konsensus bersama di antara mereka untuk memperjuangkan aspirasi umat Islam.

Kedua, pemikiran politik Islam di Indonesia ternyata tidak mengalami kemajuan, baik dari sisi konsep maupun gerakan. Tokoh-tokoh politik dari kalangan Islam masih terkesan memakai kerangka "tiga i" yaitu: (1) interest (kepentingan). Dalam kontek ini, hampir semua kepentingan elit politik hanya dikembalikan kepada partainya. Karena itu, faktor karismatik memainkan peran penting dalam memuluskan setiap kepentingan mereka, 
sehingga sering kepentingan rakyat tidak bertemu dengan kepentingan elit politik. Hal ini, tentu saja akan sangat memberikan pengaruh terhadap suara yang akan diperoleh partai Islam pada pemilu 2004 yang akan datang. (2) identity (identitas). Dalam hal ini, tidak sedikit elit maupun pendukung partai hanya mencari identitas diri mereka, khususnya bagi mereka yang jatidirinya memang belum pernah teruji dalam kancah politik. Akibatnya, untuk mencapai identitas diri ini, sering para elit politik Islam tidak memainkan politik yang santun dan bersahaja. Bahkan, tidak sedikit dari mereka yang menggunakan "suara Tuhan" dalam menghadapi kelompok lain, (3) inconsistency (inkonsistensi). Maksudnya adalah banyak tokoh politik dari kalangan Islam yang tidak konsisten antara ucapan dan perilaku. Secara konseptual, perilaku ini menunjukkan ketidakdewasaan mereka dalam memainkan peran politik disaat mereka memegang jabatan politik.

Ketiga, masih banyak ditemukan ketegangan di antara pemikir politik dari kalangan Islam yang sulit mempertemukan arus kelompok yang mempertahankan nilai-nilai Islam dengan kelompok yang mengedepankan nilai-nilai sekuler. Adanya "pemaksaan" dan "pencibiran" dalam bentuk debat publik merupakan bukti konkrit bahwa perjalanan pemikiran politik Islam di Indonesia memang belum menemukan suatu titik temu. Perdebatan demi perdebatan yang terjadi, sesungguhnya disebabkan oleh perbedaan cara pandang dan pendekatan yang digunakan. Dalam hal ini, perlu dibangun common understanding dalam merealisasikan sikap dan perilaku politik yang tidak bertentangan dengan ajaran-ajaran Islam.

Namun demikian, kajian ini masih menyisakan beberapa pertanyaan untuk dijawab oleh pemerhati Islam politik di Indonesia. Sebab, konsentrasi kajian ini hanya pada perjalanan Islam politik antara tahun 1998-2001. Harus diakui, terpilihnya Megawati menjadi presiden, juga memberikan suatu pertanyaan besar, "bagaimana mungkin" partaipartai yang semula menentangnya menjadi presiden kemudian berubah mendukung. Begitu juga, "bagaimana mungkin" Abdurrahman Wahid yang diangkat menjadi Presiden melalui konsensus bersama, kemudian dijatuhkan dengan melibatkan kelompok Islam sekular (PDI-P). Untuk memandang kasus-kasus tersebut dari perspektif hukum Islam, tentunya diperlukan kerja keras para pemerhati Islam politik, agar penjelasannya tidak secara kontemplatif, melainkan secara investigatif. 


\section{DAFTAR PUSTAKA}

Abdillah, Masykuri, "Ulama dan Politik", dalam Abdul Mu'nim DZ (ed.), Islam di Tengah Arus Transisi, Jakarta: Kompas, 2000.

Abshar-Abdalla, Ulil, "Partai, Civic Education dan Wilayah "Netral Politik", Tashwirul Afkar, No. 4, Tahun 1999.

Abueva, Jose, "Demokratisasi di Indonesia: Harmonisasi antara Elemenelemen Utama dengan Nilai-nilai Universal Demokrasi dan Hak Azasi Manusia”, Jumal Demokrasi \& HAM, Vol. 1, No. 3, MaretJuni 2001.

Akhmadi, Heri, "Habibie itu Soehartois", Oposisi, No. 37, Thn. 1, 14-20 April 1999.

Alawiyah AS, Tuty, "Politik dan Wanita: Pendekatan Hak dan Kewajiban", dalam Abu Zahra (ed.), Politik Demi Tuban: Nasionalisme Religius, Bandung: Pustaka Hidayah, 1999.

Amriel, Reza Indragiri, "Siapkah PDI-P Jadi Demokrasi Sejati?”, Republika, 1 April 2000.

Anonim, "Nepotisme Demi Suami Hingga Non-Muslim", Tekad, No. 31, 21 Mei-6 Juni 1999.

Asmin, Yudian W., "Posisi Alumni Islamic Studies dalam Percaturan Pemikiran Islam Indonesia Abad XXI", dalam Yudian W. Asmin (ed.), Pengalaman Belajar Islam di Kanada, Yogyakarta: Titian Ilahi Press, 1997.

Asshiddiqie, Jimly, "Demokratisasi Pemilihan Presiden dan Peran MPR di Masa Depan", Jumal Demokrai \& HAM, Vol. 1, No. 1, MeiAgustus 2000.

Axford, Barrie dan Ben Rosamond , "Political Participation", dalam Barrie Oxford et.al., Politic An Introduction, London: Routledge, 1997.

Azra, Azyumardi, "Faktor Islam di Indonesia Pasca-Soeharto", dalam Chris Manning dan Peter Van Diermen (ed.), Indonesia di Tengah Transisi: Aspek-Aspek Sosial Reformasi dan Krisis, Landung Simatupang et.al. (terj.). Yogyakarta: LKIS, 2000.

, "The Islamic Factor in Post-Soeharto Indonesia", Profetika Jurnal Studi Islam, Vol. 1, No. 2, Juli 1999.

, "Kian Meluas, Penggunaan Simbol Agama", Tasbwirul Afkar, No. 2, 1999. 
, Pendidikan Islam: Tradisi dan Modernisasi Menuju Milenium Baru, Jakarta: Logos, 1999.

"The Rise of Muslim Elite Schools: A New Pattern of "Santrinization": in Indonesia", Al-Jämi'ah, No. 64, 1999.

Al-Barsani, Nur Iskandar, "Langkah Mundur; Menggunakan Asas Sektarian", Tashwirul Afkar, No. 4, 1999.

Baehaqi, Ahmad, Islam dan Nasionalisme (Analisis Terbadap Nasionalisme Partai Kebangkitan Bangsa, Skripsi S. Ag. Fakultas Syari'ah Jurusan Jinayah al-Siyāsah, IAIN Sunan Kalijaga Yogyakarta, 2001.

Barton, Greg, Abdurrabman Wabid: Muslim Democrat, Indonesian President (A view from the Inside), Sydney: University of New South Wales, 2002.

Bush, Robin, "Redefining "Political Islam" in Indonesia: Nahdlatul Ulama and Khittah '26", Studia Islamika, Vol. 7, No. 2, 2000.

Cottam, Martha L. dan Richard W. Cottam, Nationalism \&o Politics: The Political Behavior of Nation States, London: Lynne Rienner, 2001.

Crouch, Harold, "Kemenangan Mega Bukan Kemenangan Reformis", dalam Gouzali Saydam (ed.), Dari Balik Suara ke Masa Depan Indonesia: Potret Konflik Politik Pasca Pemilu dan Nasib Reformasi, Jakarta: RajaGrafindo Persada, 1999.

Daman, H. Rozikin, Membidik NU: Dilema Percaturan Politik NU Pasca Khittah, Yogyakarta: Gama Media, 2001.

Dhakidae, Daniel et.al. (ed.), Wajah Dewan Pervakilan Rakyat Republik Indonesia Pemiliban Umum 1999, Jakarta: Kompas.

Effendy, Bahtiar, "Disartikulasi Pemikiran Politik Islam?" dalam Olivier Roy, Gagalnya Islam Politik, Harimurti dan Qomaruddin SF (terj.), Jakarta: Serambi Ilmu Semesta, 2002.

, Teologi Baru Politik Islam: Pertautan Agama, Negara, dan Demokrasi, Yogyakarta: Galang Press, 2001.

, "Politik Islam Pasca Orde Baru: Sintesa antara Substansialisme dan Simbolisme?", Republika, 15-16 November 1999.

Esposito, John L. dan John O. Voll, Demokrasi di Negara-Negara Muslim: Problem dan Prospek, Bandung: Mizan, 1999.

Evans, Kevin R., "Sistem Baru, Suasana Baru Pemilu 1999 yang Dinanti", dalam Julia I Suryakusuma, et.al., Almanak Parpol Indonesia, Jakarta: API, 1999.

Al-Faruqi, Jabir, "Ulama, Pemilu dan Etika Politik", dalam Abdul Mu'nim DZ (ed.), Islam di Tengah Arus Transisi, Jakarta: Kompas, 2000. 
Fatah, Eep Saefulloh, "Masa Depan Politik Islam: dari Pusaran Menuju Arus Balik", dalam Abu Zahra (ed.), Politik Demi Tuban: Nasionalisme Religius, Bandung: Pustaka Hidayah, 1999.

, "Menuju Masa Depan Politik Islam yang Toleran: Membangun Publik dan Oposisi," (Makalah dikirim kepada penulis melalui email, fatah.1@osu.edu, 20 Februari 2002).

, "Saya Kira, Popularitas Amien Luar Biasa", dalam Hairus Salim (ed.), Tujub Mesin Pendulang Suara: Perkenalan, Prediksi, Harapan Pemilu 1999, Yogyakarta: LKIS, 1999.

, "Menuju Format Baru Politik Islam: Belajar dari Kekeliruan Politik Lama", dalam Abu Zahra (ed.), Politik Demi Tuban: Nasionalisme Religius, Bandung: Pustaka Hidayah, 1999.

Fatwa, A.M., "Satu Islam Banyak Partai”, dalam Abdul Mu'nim DZ (ed.), Islam di Tengab Arus Transisi, Jakarta: Kompas, 2000.

Federspiel, Howard M., "Indonesia, Islam, and American Policy", (Makalah dipublikasikan yang diberikan kepada penulis melalui wawancara via email, 10 Maret 2002).

Forrester, Geoff \& R.J. May (ed.), The Fall of Soebarto, Singapore: Select Books, 1999.

(ed.), Post-Soebarto Indonesia: Renewal or Chaos?, Singapore: Institute of Southeast Asian Studies, 1999.

Gautama, Sidarta dan Aris Boediono, Moralitas Politik dan Pemerintahan yang Bersih, Jakarta: Raja Grafindo Persada, 1999.

Gazali, Effendi, "Kecerdasan Emosional: Tambahan untuk Diskusi Denny J.A. dan H.A. Sumargono", dalam Abdul Mu'nim DZ (ed.), Islam di Tengah Arus Transisi, Jakarta: Kompas, 2000.

Gunther, Richard, "Opening a Dialogue on Institutional Choice in Indonesia: Presidential, Parliamentary and Semi-Presidential Systems", dalam R. William Liddle (ed.), Crafting Indonesia Democracy, Bandung: Mizan, 2001.

, "Relative Merits (and Weakness) of Presidential, Parliamentary and Semi-Presidential Systems: Opening a Dialogue on Institutional Choice in Indonesia", Jurnal Demokrasi \& $H A M$, Vol. 1, No. 1, Mei-Agustus, 2000.

Husaini, Adian, Yusril Versus Masyumi: Kritik Terbadap Pemikiran Modernisme Islam Yusril Ihza Mahendra, Jakarta: Dea Press, 2000. 
JA, Denny, “"Status Quo" atau Politik Sekuler?”, dalam Abdul Mu'nim DZ (ed.), Islam di Tengah Arus Transisi, Jakarta: Kompas, 2000.

, "Agama dalam Orde Demokrasi: Jawaban untuk H.A. Sumargono", dalam Abdul Mu'nim DZ (ed.), Islam di Tengah Arus Transisi, Jakarta: Kompas, 2000.

, "Pelajaran dari Turki: Mengendalikan Politisasi Agama", Kompas, 15 Mei 1997.

, "Islam, Negara Sekuler, dan Demokrasi”, Republika, 19 Juni 1997.

Jalil, Matori Abdul, "PKB Tidak Akan Mengekploitasi Emosi Umat Islam", dalam Hairus Salim (ed.), Tujub Mesin Pendulang Suara: Perkenalan, Prediksi, Harapan Pemilu 1999, Yogyakarta: LKIS, 1999.

Jamhari, "Islamic Political Parties: Threats or Prospect?", dalam Geoff Forrester (ed.), Post-Soeharto Indonesia: Renewal or Chaos?, Singapore: Institute of Southeast Asian Studies, 1999.

Kantaprawira, Rusadi, “Ada yang Terlupakan oleh PDI-P”, dalam Gouzali Saydam (ed.), Dari Balik Suara ke Masa Depan Indonesia: Potret Konflik Politik Pasca Pemilu dan Nasib Reformasi, Jakarta: RajaGrafindo Persada, 1999.

Kuntowijoyo, "Enam Alasan untuk Tidak Mendirikan Parpol Islam", dalam Sahar L. Hassan et.al. (ed.), Memilih Partai Islam: Visi, Misi, dan Persepsi, Jakarta: Gema Insani Press, 1998.

, Muslim Tanpa Masjid: Esai-Esai Agama, Budaya, dan Politik dalam Bingkai Strukturalisme Transendental, c. 2. Bandung: Mizan, 2001.

Liddle, R. William dan Saiful Mujani, "The Islamic Challenge to Democratic Consolidation in Indonesia (Makalah disampaikan dalam International Conference "The Challenge of Democracy in Muslim Countries", Radisson Yogya Plaza Hotel, Yogyakarta, 25 Maret 2002).

, "Introduction: Crafting Indonesian Democracy", dalam R. William Liddle (ed.), Crafting Indonesia Democracy, Bandung: Mizan, 2001.

, "Islam, Kultur Politik, dan Demokratisasi: Sebuah Telaah Komparatif Awal", Jumal Demokrasi \&o HAM, Vol. 1, No. 1 MeiAgustus 2000.

Maarif, Ahmad Syafii, "Soekarno Memulai, Soeharto Menyempurnakan, dan Habibie yang Jadi Korban”, Republika, 19 November 1999. 
Ma'arif, Zaenal, "Agama, Ekonomi dan Politik: Peranan Ulama dan Pengusaha dalam Kemenangan Partai Persatuan Pembangunan (PPP) di Jepara pada Pemilu 1999”, Profetika: Jurnal Studi Islam, Vol. 3, No. 2, Juli 2001.

Machasin, "Democracy and Shari'a in Islamic Doctrine and History", (Makalah disampaikan dalam International Conference "The Challenge of Democracy in Moslem Countries" di Radisson Hotel Yogyakarta, 25 Mei, 2002).

Madjid, Nurcholish, Tradisi Islam: Peran dan Fungsinya dalam Pembangunan, Jakarta: Paramadina, 1997.

"Simbol dan Simbolisme Keagamaan Populer serta Pemaknaannya dalam Perkembangan Sosial-Politik Nasional Kontemporer", Mukaddimab: Jurnal Studi Islam, No. 8, Th. V, 1999.

, Cita-Cita Politik Islam Era Reformasi, Jakarta: Paramadina, 1999.

, "Partai Keadilan Nanti Muncul Sebagai Partai Penting", dalam Hairus Salim (ed.), Tujub Mesin Pendulang Suara: Perkenalan, Prediksi, Harapan Pemilu 1999, Yogyakarta: LKiS, 1999.

, "Beberapa Renungan Kehidupan Keagamaan untuk Generasi Mendatang", dalam Edy A. Effendy (ed.), Dekonstruksi Islam: Mazhab Ciputat, Bandung: Zaman Wacana Mulya, 1999.

"Habibie: An Example of a Weak President that Should be Maintained Until the Election", Tempo Interaktif, Edisi 25/03, 22 Agustus 1998.

Magnis-Suseno, Franz, "Langsir Keprabon: New Orde Leadership, Javanese Culture, and the Prospects for Democracy in Indonesia", dalam Geoff Forrester (ed.), Post-Soeharto Indonesia: Renewal or Chaos?, Singapore: Institute of Southeast Asian Studies, 1999.

Mahendra, Yusril Ihza, "Partai Alternatif Era Reformasi", dalam Sahar L. Hassan et.al. (ed.), Memilib Partai Islam: Visi, Misi, dan Persepsi, Jakarta: Gema Insani Press, 1998.

Mardjono, Hartono, "Caleg Non-Muslim dan Stembus Accord", dalam Gouzali Saydam (ed.), Dari Balik Suara ke Masa Depan Indonesia: Potret Konflik Politik Pasca Pemilu dan Nasib Reformasi, Jakarta: RajaGrafindo Persada, 1999.

Mu'allim, Amir, "Bangkitnya Kaum (Islam) Abangan", UNISLA, No. 41, 2000.

Mujani, Saiful, “Oposisi Islam?”, Republika, 27-28 Desember 1999. 
Mudzhar, Atho, "Studi Hukum Islam dengan Pendekatan Sosiologi", (Pidato Pengukuhan Guru Besar Madya Ilmu Sosiologi Hukum Islam Disampaikan di Hadapan Rapat Senat Terbuka IAIN Sunan Kalijaga Yogyakarta, 15 September 1999).

Najib, Muhamad, "Evaluasi dan Analisa Hasil Pemilu", http://www.eamienrais.com/target.asp?judul=pemilu, 23 April 2002.

Noer, Deliar, "Mengapa Partai Islam", dalam Sahar L. Hassan et.al. (ed.), Memilib Partai Islam: Visi, Misi, dan Persepsi, Jakarta: Gema Insani Press, 1998.

Nugraha, Iman, et.al., Sikap Kami: Kumpulan Seruan, Pernyataan Sikap, Bayanat dan Pidato Politik DPP Partai Keadilan, Jakarta: HUMAS DPP Partai Keadilan, 2001.

Platzdasch, Bernhard, "Reaksi Islam Terhadap Presiden Wanita", Chris Manning dan Peter Van Diermen (ed.), Indonesia di Tengab Transisi: Aspek-Aspek Sosial Reformasi dan Krisis, Landung Simatupang et.al. (teri.), Yogyakarta: LKiS, 2000.

Purwoko, "Siapa Putihkan Utang Cendana Rp 600 Trilyun?”, Vokal, No. 18, edisi 22-28 April 1999.

Putri, Agung, "Demokrasi dan Tuntutan Hak Asasi Manusia di Indonesia", dalam Julia I Suryakusuma, et. al., Almanak Parpol Indonesia, Jakarta: API, 2000.

Qomar, Mujamil, NU 'Liberal": dari Tradisionalisme Ablusunnab ke Universalisme Islam, Bandung: Mizan, 2002.

Rahim, Rohani Abdul, Muslim in Indonesia and the Nation of an Islamic State, Malaysia: ABIM, 1991.

Rahmat, M. Imdadun, et.al., "Partai-Partai Islam: Trasformasi Gerakan Islam dan Ruang Demokrasi", Tashwirul Afkar, No. 4, 1999.

Rais, Amien, "Islam and Politics in Contemporary", dalam Geoff Forrester (ed.), Post-Soebarto Indonesia: Renewval or Chaos?, Singapore: Institute of Southeast Asian Studies, 1999.

, "Dalam Istilah Politiknya Disebut Political Standstill", dalam Hairus Salim (ed.), Tujub Mesin Pendulang Suara: Perkenalan, Prediksi, Harapan Pemilu 1999, Yogyakarta: LKiS, 1999. , Membangun Politik Adilubung: Membumikan Taubid Sosial Menegakkan Amar Ma'ruf Nahi Mungkar, Bandung: Zaman Wacana Mulya, 1998.

Rumadi, “Jejak-Jejak Liberalisme NU”, Tashwirul Afkar, No. 9, 2000. 
Samad, Paridah Abd., General Wiranto: The Man Emerging from the Midst of Indonesian Reformation, Kuala Lumpur: Affluent Master Sdn. Bhd., 1999.

Shihab, M. Quraish, Wawasan Al-Quran: Tafsir Maudbu'i atas Pelbagai Persoalan Umat, c. 9. Bandung: Mizan, 1999. , "Perempuan sebagai Pemimpin", dalam Abu Zahra (ed.), Politik Demi Tuban: Nasionalisme Religius, Bandung: Pustaka Hidayah, 1999.

Siradj, Said Aqil, Islam Kebangsaan: Fiqih Demokratik Kaum Santri, Jakarta: Pustaka Ciganjur, 1999.

, "Wanita Presiden", dalam Abu Zahra (ed.), Politik Demi Tuban: Nasionalisme Religius, Bandung: Pustaka Hidayah, 1999.

Signh, Bilveer, Succession Politics in Indonesia: The 1998 Presidential Elections and the Fall of Subarto, London: Macmillan, 2000.

Soekarnoputri, Megawai, "Pidato Politik Ketua Umum PDI Perjuangan Dalam Rangka Menyambut Kemenangan Rakyat pada Pemilu 1999", http://www.megaforpresident.org/main /pidato.html 26 April 2002.

Sudibyo, Agus, "Dinamika Corak Berpolitik Elite NU: Tarik-Menarik yang Tak Kunjung Usai," Tashwirul Afkar, No. 9, 1999.

Suhelmi, Ahmad, Soekarno Versus Natsir: Kemenangan Barisan Megawati Reinkarnasi Nasionalis Sekuler, Jakarta: Darul Falah, 1999.

Sulaiman, Sadek J., "Democracy and Shura", dalam Charles Kurzman (ed.), Liberal Islam: A Sourcebook, New York: Oxford University Press, 1998.

Suryadinata, Leo, Elections and Politic in Indonesia, Singapore: Institute of Southeast Asian Studies, 2002.

Suryakusuma, Julia I., "Ketika Anarki Bukan Anarki: Kekerasan dan Demokrasi di Indonesia", dalam Julia I Suryakusuma, et.al., Almanak Parpol Indonesia, Jakarta: API, 2000.

Thohari, Hajriyanto Y., "Negara Santri": Menengok Tesis Cak Nur", dalam Abdul Mu'nim DZ (ed.), Islam di Tengah Arus Transisi, Jakarta: Kompas, 2000.

Tim Amanat, "Benarkah Status Quo Baru Dibidani PDI Perjuangan", dalam Gouzali Saydam (ed.), Dari Balik Suara ke Masa Depan Indonesia: Potret Konflik Politik Pasca Pemilu dan Nasib Reformasi, Jakarta: RajaGrafindo Persada, 1999. 
Turmudi, Endang, "The Challenge of Democratization in Indonesia's Multicultural Society", dalam Murni Jalam et.al. (ed.), Comunal Conflicts in Comtemporary Indonesia, Jakarta: Pusat Bahasa dan Budaya, 2002.

Umar, Nasaruddin,"Perspektif Jender dalam Islam", Paramadina: Jurnal Pemikiran Islam, Vol. 1, No. 1 Juli-Desember 1998. , "Metode Penelitian Berspektif Jender Tentang Literatur Islam", Al-Jämi'ah, No. 64, 1999.

Yafie, Ali, "MUI Hanya Memberikan Bimbingan Moral", dalam Gouzali Saydam (ed.), Dari Balik Suara Ke Masa Depan Indonesia: Potret Konflik Politik Pasca Pemilu dan Nasib Reformasi, Jakarta: RajaGrafindo Persada, 1999.

Zed, Mestika, "Hidden History: Sejarah Kebrutalan dan Kejahatan Negara Melawan Kemanusiaan. Isu-Isu dan Strategi dalam Konteks Sejarah Indonesia", Jurnal Demokrasi \& HAM, Vol. 2, No. 1, Februari-Mei 2002.

Zon, Fadhli, "Pemilu 1999: Kemenangan Status Quo Baru?", dalam Gouzali Saydam (ed.), Dari Balik Suara Ke Masa Depan Indonesia: Potret Konflik Politik Pasca Pemilu dan Nasib Reformasi, Jakarta: RajaGrafindo Persada, 1999. 